\title{
Model-Based Solution for Upgrading Nitrogen Removal for a Full-Scale Municipal Wastewater Treatment Plant with CASS Process
}

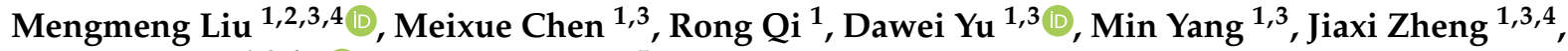 \\ Yuansong Wei ${ }^{1,3,4, *(D)}$ and Haizhou $\mathrm{Du}^{5}$
}

check for

updates

Citation: Liu, M.; Chen, M.; Qi, R.; Yu, D.; Yang, M.; Zheng, J.; Wei, Y.; $\mathrm{Du}, \mathrm{H}$. Model-Based Solution for Upgrading Nitrogen Removal for a Full-Scale Municipal Wastewater Treatment Plant with CASS Process Processes 2021, 9, 527. https:// doi.org/10.3390/pr9030527

Received: 13 January 2021

Accepted: 2 March 2021

Published: 15 March 2021

Publisher's Note: MDPI stays neutral with regard to jurisdictional claims in published maps and institutional affiliations.

Copyright: (c) 2021 by the authors. Licensee MDPI, Basel, Switzerland. This article is an open access article distributed under the terms and conditions of the Creative Commons Attribution (CC BY) license (https:/ / creativecommons.org/licenses/by/ $4.0 /)$.
1 State Key Joint Laboratory of Environment Simulation and Pollution Control, Research Center for Eco-Environmental Sciences, Chinese Academy of Sciences, Beijing 100085, China; m_mliu@163.com (M.L.); mxchen@rcees.ac.cn (M.C.); qirong@rcees.ac.cn (R.Q.); dwyu@rcees.ac.cn (D.Y.); 18732186612@163.com (M.Y.); talenthunterjx@163.com (J.Z.)

2 Yangtze River Ecological Environment Engineering Research Center, China Three Gorges Corporation, Beijing 100038, China

3 Laboratory of Water Pollution Control Technology, Research Center for Eco-Environmental Sciences, Chinese Academy of Sciences, Beijing 100085, China

4 University of Chinese Academy of Sciences, Chinese Academy of Sciences, Beijing 100049, China

5 Zhangjiakou Xishan Wastewater Treatment Co., Ltd., Zhangjiakou 076250, China; 18813012008@163.com

* Correspondence: yswei@rcees.ac.cn

\begin{abstract}
Aiming at providing cost-effective approach for upgrading the existing municipal wastewater treatment plants in the cold region of China to meet more stringent discharge standards of nitrogen removal, a full-scale sewage treatment plant with the CASS process was selected through focusing on biological process, key equipment and hydrodynamics in bioreactors by the activated sludge model 1 (ASM1) and computational fluid dynamics (CFD) model. Influent COD fractions and the key characteristic parameters $\left(Y_{\mathrm{H}}\right.$ and $\left.b_{\mathrm{H}}\right)$ of the activated sludge were determined through the respirometry at temperatures of $10^{\circ} \mathrm{C}$ and $20^{\circ} \mathrm{C}$, respectively. The layout of submerged agitator installation in the bioreactor of the CASS process was optimized through CFD simulation. The calculation of the average relative deviation (less than $20 \%$ ) between simulated data and the operation data, demonstrated that the ASM1 model could be reasonably used in the wastewater treatment plant simulation. The upgrade solution based on modelling of ASM1 and CFD was successfully applied in practice, which not only made the effluent $\mathrm{COD}, \mathrm{NH}_{4}{ }^{+}-\mathrm{N}$ and TN concentrations meet with the discharge standard of Grade I-A, but also reduced the energy consumption by $25 \%$ and $16.67 \%$ in summer and winter, respectively. After upgrading, microbial diversity increased in both summer and winter, with an especially significant increase of the relative abundance of denitrifying bacteria.
\end{abstract}

Keywords: activated sludge model No.1 (ASM1); sensitivity analysis; full-scale; CASS WWTP; CFD

\section{Introduction}

According to United Nations statistics, by 2025, two-thirds of the world's population may face water shortages [1]. If discharged without treatment, municipal and industrial wastewater will cause damage to the aquatic ecosystem through eutrophication and fish poisoning, as well as adverse effects on human health due to the discharge of pathogenic organisms in sewage to recreational water bodies [2]. However, with proper treatment, water pollution can be minimized and wastewater can be used as a resource for nutrients and recycled water. Therefore, wastewater treatment technology plays a vital role in realizing the sustainable future of human society [3].

Developed countries have experienced the process of "pollution first, treatment later" of the water environment. Domestic sewage treatment developed rapidly after the 1970s. By the end of the 1990s, the average domestic sewage treatment rate in developed countries 
had reached a relatively high level of over 80\% [4]. Among them, New Zealand, Singapore, and Northern Europe have basically achieved 100\% collection and processing rates. In developed countries, sewage treatment facilities are mainly small and medium-sized. For example, there are more than 14,780 sewage treatment plants nationwide in the United States, with an average daily processing water volume of about 6000 tons per plant, of which small and medium-sized sewage treatment plants with a capacity of less than 50,000 tons per day account for about $85 \%$ of the total [5]. The United States is currently the country with the largest number of sewage treatment plants in the world, with an average of 1 in 5000 people, $78 \%$ of which are secondary biological treatment plants; the United Kingdom has about 8000 treatment plants with an average of 1 in 7000 people, almost all of which are secondary biological treatment plants. There are about 630 urban wastewater treatment plants in Japan, with an average of 1 in 200,000 people, but secondary treatment plants and advanced treatment plants account for $98.6 \%$; Sweden is currently the country with the most popular sewage treatment facilities, with a sewer penetration rate of over $99 \%$, with an average of 1 in 5000 people, of which $91 \%$ are secondary biological treatment plants [6].

With increasing emphasis on China's water environment protection, more stringent regulations and standards have been legislated governing the discharge of organic pollutant, nitrogen and phosphorus in effluent of municipal wastewater treatment plants (WWTPs). Therefore, there is a significant need to upgrade the existing municipal WWTPs to meet the strict discharge standards. For example, the Action Plan for Water Pollution Prevention and Control issued in 2015 by China [7] requests effluent from all WWTPs into the receiving water bodies to meet with requirements of the Grade I-A of the Discharge Standard of Pollutants for Municipal Wastewater Treatment Plant (GB 18918-2002), e.g., chemical oxygen demand (COD), total nitrogen (TN), total phosphorus (TP) concentration limits of effluent should be upgraded to $50 \mathrm{mg} / \mathrm{L}, 15 \mathrm{mg} / \mathrm{L}$ and $0.5 \mathrm{mg} / \mathrm{L}$ of the Grade I-A from $60 \mathrm{mg} / \mathrm{L}, 20 \mathrm{mg} / \mathrm{L}$ and $1.0 \mathrm{mg} / \mathrm{L}$ of the Grade I-B, respectively. It was reported that the total municipal wastewater discharged in China was 49.24 billion tons in 2017, increased by $30.02 \%$ and $5.53 \%$ compared with 2010 and 2015, respectively, along with rapid urbanization [8]. Among the over 4000 municipal WWTPs in China, the small and mid-scale municipal WWTPs with the design capacity less than $50,000 \mathrm{~m}^{3} / \mathrm{d}$ accounted for $83.3 \%$ in 2017 [9], most of which need to be upgraded or optimized to meet the discharge requirements of Grade I-A. Generally, the upgrading of the existing sewage treatment plants can be considered from two perspectives: one is only the effluent water quality of WWTPs, the other is both the effluent water quality and the design capacity of WWTPs [10], and the most important goal of upgrading existing municipal wastewater treatment plants is to ensure high treatment efficiency to meet wastewater quality standards, while keeping investment and operating costs to a minimum by focusing on energy saving and cost reduction methods of bioprocesses, key equipment and hydrodynamics in bioreactors. However one of major challenges of upgrading the existing municipal WWTPs in China, especially those in the small and mid-size cities \& towns of the cold region, to meet the Grade I-A standards of GB 18918-2002 is the TN limit of $10 \mathrm{mg} / \mathrm{L}$ in the effluent while keeping the investment and operating cost as low as possible [11,12].

Wastewater treatment can be divided into physical, chemical and biological treatment methods based on the type of water quality [13]. According to the degree of treatment, they can also be divided into primary, secondary and tertiary treatment methods [14]. The physical treatment method of urban sewage is a method that uses physical action to separate and remove pollutants in sewage [15], including screening and interception, gravity separation, centrifugal separation. Chemical treatment methods are rarely used in urban sewage treatment, and generally involve other chemical methods in urban water supply treatment, such as neutralization, oxidation-reduction, ion exchange, and electrolysis, which are mainly used for industrial wastewater treatment [16]. Chemical method must be used in conjunction with the physical method. Before chemical treatment, precipitation and filtration are often used as pre-treatment; in some cases, physical means such as 
precipitation and filtration are required as post-treatment of chemical treatment. Biological treatment is a method that uses the metabolism of microorganisms to remove organic substances in sewage. Commonly used are activated sludge method, biofilm method, as well as oxidation pond and sewage land treatment method [17].

It is well known that the activated sludge processes are the most applied biological approach for nutrient removal for municipal wastewater treatment in the world. Traditionally, municipal WWTPs have been designed and operated using empirical steady-state equations or 'rules of thumb', introducing conservative safety factors that have led to the over-dimensioned, expensive construction and unstable functioning plants [18]. Different modifications have been thus proposed for the conventional activated sludge processes to meet the strict effluent standards for COD, biological oxygen demand (BOD), nitrogen and phosphorus [19].

Due to the nonlinear dynamics and uncertainty, the internal process dynamics have multiple time scales and multivariable structures, so activated sludge wastewater treatment plants can be classified as complex systems, and such traditional approaches cannot meet increasing requirements for municipal WWTPs. Process evaluation, design optimization, and cost analysis can be performed by simulation and modeling tools [20-22]. Numerical simulation based on activated sludge models is getting an increasing attention, and these models are incorporated in commercial simulation packages such as BioWin (EnviroSim Associates, Flamborough, Ontario, Canada), GPS-X (Hydromantis Inc., Ontario, Canada) and WEST (HEMMIS Inc., East Flanders, Belgium and DHI Inc, Copenhagen, Denmark) for engineering practice $[23,24]$. Numerical simulation has been widely regarded as helpful tools for evaluation, diagnosing and optimizing WWTPs' design, and operation and control, comparison and selection of the biological treatment processes as well as upgrade of the existing WWTPs [25-27]. A series of activated sludge models (i.e., ASM1, ASM2, ASM2d, ASM3) formulated and introduced by IWA (International Water Association) have been considered as indispensable solutions in correlating the complexity of the activated sludge process and the prediction of biological treatment efficiency under dynamic conditions [28-30].

The ASM1 is the primary version, which is a structured model based on Monod kinetics to realistically predict the performance of carbon oxidation, nitrification and denitrification in activated sludge systems under aerobic and anoxic conditions. Among these available models, ASM1 has been considered as a reliable reference model due to its most widely applications for the academic and operational fields [31-33].

Nevertheless, one of the major limitations for a more widespread application of ASM is to choose a set of related parameters that are essential for achieving a good prediction of the model used [34]. In the neutral and relatively constant conditions, there are many environmental factors that influence the dynamics and stoichiometric parameters of ASM1 models, but influent characteristics and temperature are the two most common environmental factors $[30,35]$. Most of the parameters are affected by the specific components of the influent [36-38], which either promote or inhibit the values of kinetic parameters and stoichiometric coefficients.

However, the characteristics of the influent fractions can change in different seasons during one year [39]. Different seasons and influent characteristics lead to different kinetic parameters. A small water temperature range (low temperature, medium temperature, high temperature) generally causes the rate coefficient changing (e.g., $\mu_{\mathrm{H}, \max }, b_{\mathrm{A}}$ or $k_{\mathrm{h}}$ ). Moreover, almost all kinetic parameters are affected by water temperature, so the influence of temperature should be considered when setting values (Henze et al., 2000). Although many literatures have proposed different water temperature correction factors [40-43], most of them are not universally suitable for all the researches. In a word, it is necessary to simultaneously determine the concentration of influent characteristics and the key kinetic parameters at different temperatures so the models can be accurately applied to the design, operation and upgrade of existing wastewater treatment systems [30]. 
Flow and hydrodynamic characteristics play an important role in the stable operation of an activated sludge processes system, especially for the denitrification process within a limited residence time. While in most of the anaerobic or anoxic tanks, the submersible agitators were installed on the basis of general empirical guidelines, operators' experience or 'rules of thumb', which cannot guarantee the evenly mixing of the flow field. Improper installation of the agitators can also cause the damage to the blades. CFD is a powerful tool to simulate the hydrodynamics and mass transfer, and has become increasingly popular in optimizing design and operation of WWTPs [44-48], therefore such a study of the agitators' location and position in the bioreactor has become easier and less expensive.

In China, the Sequencing Batch Reactor (SBR) and its variant processes was the third widely used activated sludge process at $17.19 \%$ of municipal WWTPs, while the first two were the oxidation ditch (OD) process at $29.21 \%$ and the anaerobic-anoxic-oxic $\left(\mathrm{A}^{2} / \mathrm{O}\right)$ process at $25.45 \%$ [49]. The CASS process is a variant of the SBR process, in which nitrogen is removed mainly by simultaneous nitrification and denitrification [50]. The CASS process has been widely used in municipal and industrial WWTPs, e.g., over 400 small and midscale municipal WWTPs, especially those in cold regions of northern China because of its configuration flexibility, operational simplicity, low construction and maintenance costs, and simultaneous removal of nitrogen and phosphorus [51]. It is obvious that treatment performance of small and mid-scale municipal WWTPs in the cold regions of northern China, especially the TN removal, has significant difference in summer and winter, e.g., unstable TN removal and TN concentration of effluent usually does not meet the discharge standard in winter [52]. Considering key factors such as large fluctuations in water quality and quantity of influent, unstable performance of wastewater treatment in winter, selection of new process or optimization of the existing process, constraints of existing structure and field, and limits of capital \& operational costs, it has been suggested that the mathematical ASM model will be a very powerful and cost-effective tool for upgrading, designing, operating and optimizing existing small and medium-scale sewage treatment plants in the cold regions of northern China.

Thus, a hypothesis in this study is that the model-based upgrading of an existing full-scale WWTP is feasible through optimizing the existing biological process to comply with TN of effluent quality criteria while keeping the capital and operational costs as low as possible. A full-scale municipal WWTP with the CASS process at a design capacity of 20,000 $\mathrm{m}^{3}$ / day, located in Zhangjiakou, Hebei Province, was selected to upgrade TN removal on the basis of ASM1 modelling and optimization, as well as CFD simulation and optimization for the agitators' layout. In this study, the modelling, simulation and optimization of this full-scale CASS process WWTP was carried out by ASM1 using a commercial software package GPS-X 8.0 (Hydromantis Inc., Ontario, Canada) to evaluate the treatment performance and diagnose the bottlenecks of operation in summer and winter, determine the influent COD fractions and calibrate the model kinetic parameters. Then, an upgrade solution of this WWTP with different operational strategies and multiple optimization alternatives, as well as the optimized location and position of the agitators in CASS tank with the aid of CFD simulation, were made and carried out to make effluent quality meet the requirements of Grade I-A of the GB 18918-2002. In addition, treatment performance (especially TN removal) and energy consumption of this WWTP were compared before and after the upgrading of this WWTP, and the evolution of the microbial community of the CASS process with seasonal changes was also investigated based on high-throughput $16 S$ rRNA gene sequencing analysis.

\section{Materials and Methods}

\subsection{Full-Scale Wastewater Treatment Plant and CASS Process}

In this study, a full-scale municipal WWTP with the CASS process located in northwest of Hebei province (North China) was selected, which design capacity is $20,000 \mathrm{~m}^{3}$ of domestic wastewater per day [53]. This WWTP consists of four CASS systems arranged in parallel, mainly including a mechanical treatment unit of primary settling tank to 
remove floating and settleable solids, a biological treatment unit with activated sludge process for $\mathrm{COD}$ and nutrients removals, a sludge treatment unit of dewatering. Before upgrading, the bioreactor of the CASS consisted of a pre-denitrification anoxic zone $\left(\mathrm{L} \times \mathrm{W} \times \mathrm{H}=4.3 \mathrm{~m} \times 17.6 \mathrm{~m} \times 5.6 \mathrm{~m}\right.$, with effective volume of $\left.423.8 \mathrm{~m}^{3}\right)$, in which there are two submersible agitators installed on the opposite corners to make the anoxic tank in good mixing performance. Without submersible agitators, the aeration in the nitrification aerobic zone $(\mathrm{L} \times \mathrm{W} \times \mathrm{H}=34 \mathrm{~m} \times 17.6 \mathrm{~m} \times 6.5 \mathrm{~m}$, effective depth $5.5 \mathrm{~m}$ with working volume of $3,291.2 \mathrm{~m}^{3}$ ) was obtained with fine-pore air diffusers located at the bottom of the bioreactor to make the DO concentrations at $2-3 \mathrm{mg} \cdot \mathrm{L}^{-1}$. A schematic flow diagram of the biological step of the CASS system was shown in Figure 1a.

(a)

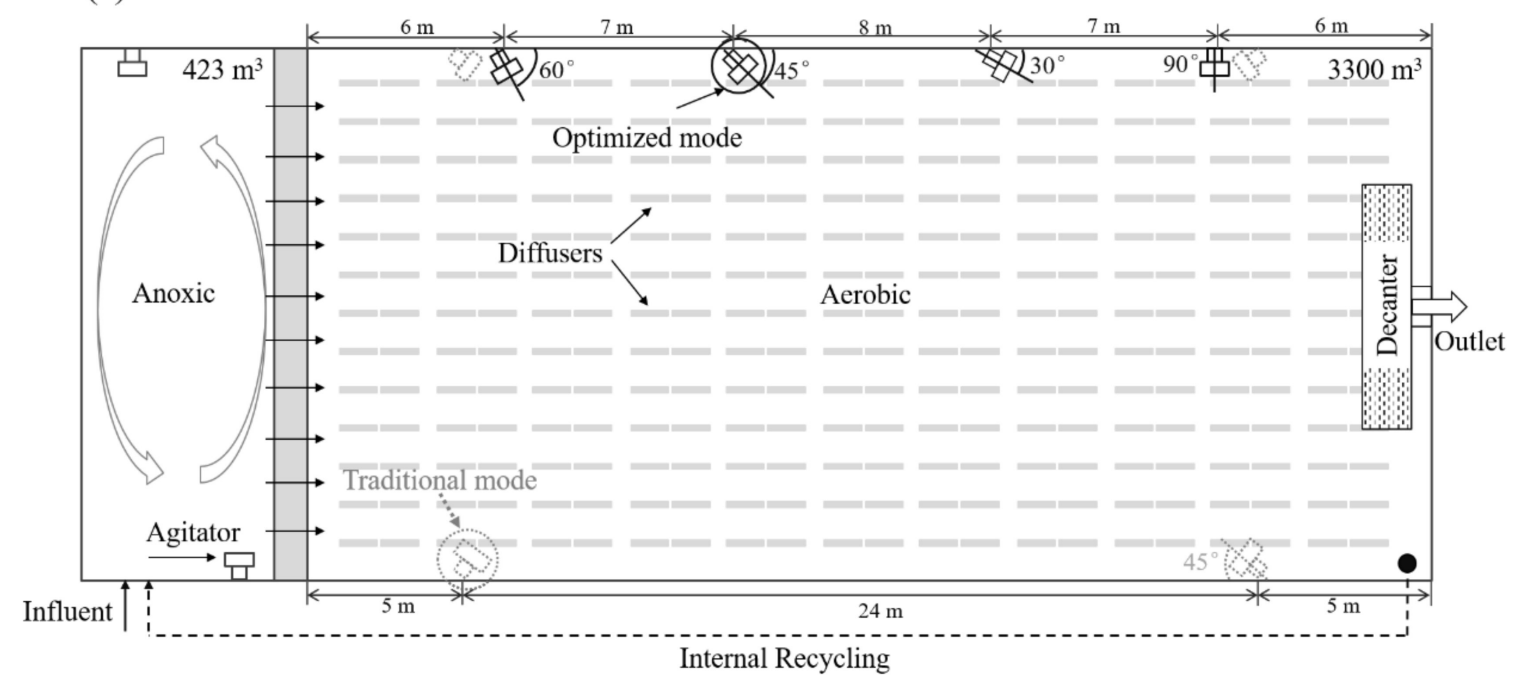

(b)

Summer mode

$90 \min$

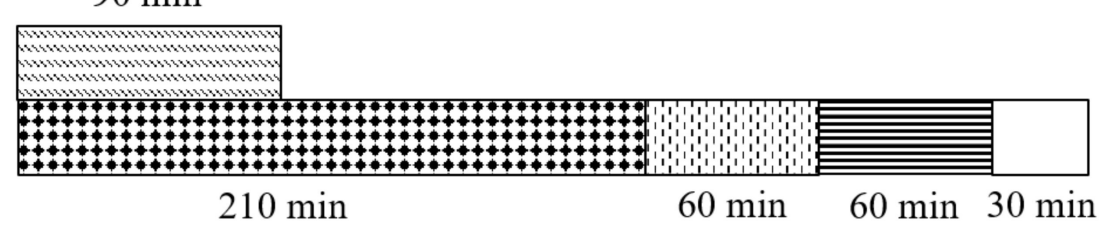

Winter mode
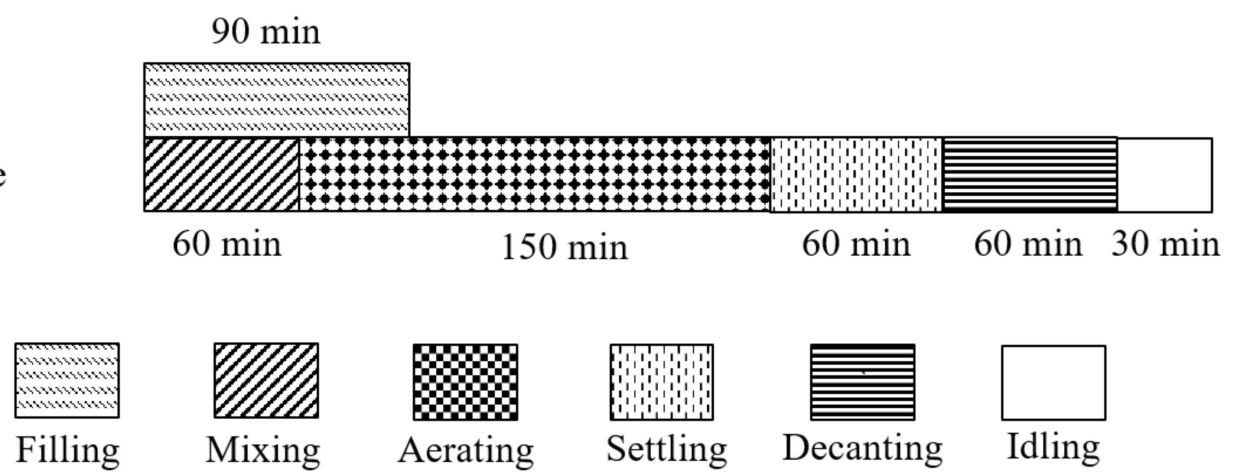

Figure 1. Schematic description of CASS and the two operation modes in summer and winter. (a) Top view of biological tank; (b) Operation strategies.

The CASS process was operated under two different strategies in summer (June, July and August) and winter (December, January and February), respectively (Figure 1b). Before upgrading, each CASS cycle was designed for $6 \mathrm{~h}$, while the effluent cannot meet discharge standard of TN limit at $15 \mathrm{mg} \cdot \mathrm{L}^{-1}$ (GB18918-2002) in winter (Figure S1). In summer mode, 
90 min was allocated to batch feeding without the submersible agitator operation and most of the denitrification process takes place in the front anoxic zone. The nitrification of ammonia nitrogen was achieved by aeration for $210 \mathrm{~min}$. For the last phase, settling and decant time were the same for $60 \mathrm{~min}$, and $30 \mathrm{~min}$ for idling phase. The only difference between the summer mode and winter mode was the first two phases. In winter mode, the first two phases consist of $60 \mathrm{~min}$ for mixing during the time of $90 \mathrm{~min}$ of filling, and the aeration phase was shortened to $150 \mathrm{~min}$. These two kinds of operation strategies depended on the influent characteristics as shown in Table 1. From the beginning of September 2018, the TN of effluent must meet Grade I-A discharge standard of GB18918-2002, while the residence time of the pre-denitrification anoxic zone is too short to meet the standard nitrogen emission. Because the wastewater filling time of a single CASS system is $90 \mathrm{~min}$, in order to ensure the continuous water supply of the four series as a whole, sometimes the idle period is increased in the operation cycle.

Table 1. Operating parameters and influent characteristics of the CASS process (data from June, 2018 and December, 2018).

\begin{tabular}{|c|c|c|c|c|}
\hline Parameter. & Operation Mode & Mean \pm SD & Minimum & Maximum \\
\hline \multirow{2}{*}{$\begin{array}{l}\text { Volume of wastewater } \\
\text { treatment }\left(\mathrm{m}^{3} \cdot \mathrm{d}^{-1}\right)\end{array}$} & Summer & $18,600 \pm 1530$ & 16,500 & 19,800 \\
\hline & Winter & $14,300 \pm 2840$ & 12,130 & 16,900 \\
\hline \multirow{2}{*}{$\begin{array}{c}\text { Wastewater } \\
\text { temperature }\left({ }^{\circ} \mathrm{C}\right)\end{array}$} & Summer & $20.3 \pm 0.74$ & 18.5 & 21.8 \\
\hline & Winter & $9.8 \pm 0.68$ & 8.1 & 11.3 \\
\hline \multirow{2}{*}{ SRT (d) } & Summer & $21 \pm 0.6$ & 20.2 & 22.3 \\
\hline & Winter & $24 \pm 0.9$ & 22.2 & 25.7 \\
\hline \multirow{2}{*}{ RAS flow rate $\left(\mathrm{m}^{3} \cdot \mathrm{d}^{-1}\right)$} & Summer & $9525 \pm 1010$ & 8991 & 10,789 \\
\hline & Winter & $12,525 \pm 1324$ & 10,991 & 15,317 \\
\hline \multirow{2}{*}{$\mathrm{pH}$} & Summer & $7.7 \pm 0.19$ & 7.26 & 7.91 \\
\hline & Winter & $7.5 \pm 0.12$ & 7.26 & 7.93 \\
\hline \multirow{2}{*}{$\mathrm{SS}\left(\mathrm{mg} \cdot \mathrm{L}^{-1}\right)$} & Summer & $126.48 \pm 24.24$ & 67 & 163 \\
\hline & Winter & $155.39 \pm 0.50 .24$ & 67 & 429 \\
\hline \multirow{2}{*}{$\mathrm{COD}\left(\mathrm{mg} \mathrm{O}_{2} \cdot \mathrm{L}^{-1}\right)$} & Summer & $341.45 \pm 61.2$ & 193 & 549 \\
\hline & Winter & $446.59 \pm 79.74$ & 318 & 689.16 \\
\hline \multirow{2}{*}{$\mathrm{BOD}_{5}\left(\mathrm{mg} \mathrm{O}_{2} \cdot \mathrm{L}^{-1}\right)$} & Summer & $157.97 \pm 37.24$ & 82 & 254 \\
\hline & Winter & $217.3 \pm 38.37$ & 129.92 & 396 \\
\hline \multirow{2}{*}{$\mathrm{TN}\left(\mathrm{mg} \mathrm{N} \cdot \mathrm{L}^{-1}\right)$} & Summer & $56.97 \pm 12.54$ & 43.8 & 79.3 \\
\hline & Winter & $90.70 \pm 8.62$ & 67.81 & 125.89 \\
\hline \multirow{2}{*}{$\mathrm{NH}_{4}{ }^{+}-\mathrm{N}\left(\mathrm{mg} \mathrm{N} \cdot \mathrm{L}^{-1}\right)$} & Summer & $48.81 \pm 11.3$ & 40.91 & 59.18 \\
\hline & Winter & $71.39 \pm 11.01$ & 47.60 & 88.70 \\
\hline \multirow{2}{*}{$\mathrm{TP}\left(\mathrm{mg} P \cdot \mathrm{L}^{-1}\right)$} & Summer & $6.9 \pm 2.63$ & 2.46 & 14.3 \\
\hline & Winter & $7.02 \pm 2.29$ & 5.88 & 8.42 \\
\hline \multirow{2}{*}{$\mathrm{C} / \mathrm{N}$ ratio } & Summer & $5.74 \pm 1.56$ & 4.79 & 9.17 \\
\hline & Winter & $5.58 \pm 1.11$ & 5.09 & 8.32 \\
\hline
\end{tabular}

To maintain the biomass, the returned sludge, nearly $50 \%$ of the influent flow rate in summer mode, while $100 \%$ in winter, from the end of SBR zone was recirculated into the anoxic basin. The MLSS was controlled at about $4000 \mathrm{mg} \cdot \mathrm{L}^{-1}$ in the main SBR zone after filling phase, while approximately $5200 \mathrm{mg} \cdot \mathrm{L}^{-1}$ after decanting with a volumetric exchange ratio of $22.73 \%$ for each cycle. The SRT was controlled at nearly $21 \mathrm{~d}$ by discharging an appropriate amount of sludge.

\subsection{ASM1 Modelling}

The ASM1 was used in this study for its good description of the activated sludge process $[41,54]$. Firstly, the influent COD fraction, heterotrophic yield, $Y_{\mathrm{H}}$, and heterotrophic decay rate, $b_{\mathrm{H}}$, were estimated by the respirometry test in summer $\left(20^{\circ} \mathrm{C}\right)$ and winter 
$\left(10^{\circ} \mathrm{C}\right)$, respectively. Secondly, the essential kinetic and stoichiometric model parameters were determined through sensitive analysis. Thirdly, the results of the simulation based on the field investigation data of this WWTP were compared with the actual treated effluent water quality. Fourthly, an upgrade solution with different operational strategies and multiple optimization alternatives, as well as the optimized location of the stirrers in CASS tank with the aid of CFD simulation, were put forward and carried out to achieve better effluent quality.

\subsection{Respirometry Test}

Respirometry is the useful method in diagnose the COD fractions and some key model parameters [37,41]. This method has been widely used in the ASM modelling [55-57]. The respirometry experiments were carried out in a $2 \mathrm{~L}$ closed vessel which was magnetic stirred to make the proportional liquor well-mixed, and the dissolved oxygen (DO) electrode (Oxi 3205, WTW, Berlin, Germany) was fixed in the vessel to monitor the DO data intermittently. The temperature of these experiments was kept at $20^{\circ} \mathrm{C}$ for summer samples while $10^{\circ} \mathrm{C}$ for winter samples throughout the respirometry test period.

The activated sludge samples taken from the CASS system in different seasons (summer and winter in 2018) were aerated for $24 \mathrm{~h}$ before use to ensure the endogenous state at the beginning of the experiments. After aeration, in order to remove the external COD, the static sedimentary sludge was then washed for three times with distilled water. Six hundred $\mathrm{mL}$ wastewater and $400 \mathrm{~mL}$ washed sludge were mixed in a closed vessel according to the actual system operation F/M value. All tests were carried out under the conditions of adding $20 \mathrm{mg} \cdot \mathrm{L}^{-1}$ of nitrification inhibitor (Allylthiourea, ATU, Shanghai, China) to limit the oxygen consumption by nitration. DO concentration in the vessel was recorded intermittently with the dissolved oxygen electrode (Oxi 340i, WTW, Berlin, Germany). The first step was to rapidly increase the DO of the mixture up to $6 \mathrm{mg} \cdot \mathrm{L}^{-1}$ with strong aeration followed by a decrease phase of DO concentration to $2 \mathrm{mg} \cdot \mathrm{L}^{-1}$ by turning off the air pump. The data sampling frequency is once every $10 \mathrm{~s}$, which is relatively high in the initial stage for the high OUR rate due to $S_{\mathrm{s}}$ degradation. The dissolved oxygen in the reactor will drop to $2 \mathrm{mg} \cdot \mathrm{L}^{-1}$ in a short period of time $(<5 \mathrm{~min})$. At this time, the data reading will be suspended, the aerator will be used to oxygenate the mixture system in the vessel. The aerator was turned off after the DO was above $6 \mathrm{mg} / \mathrm{L}$ again. Then, the change of the $\mathrm{DO}$ in the reactor was recorded intermittently. The above steps were continued until the value of the oxygen consumption rate becomes constant. Thus, the OUR of the sludge can be calculated by the slope of the DO concentration reduction during period in which the aeration was turned off.

\subsubsection{Heterotrophic Yield $Y_{H}$}

The actual heterotrophic yield coefficient, $Y_{\mathrm{H}}$, which must be known before determining the soluble rapidly biodegradable organic, $S_{\mathrm{S}}[37,58]$. It was evaluated by a respirometry test in which four different concentrations of fully biodegradable organic substrate were added to the our system in which the sludge was in endogenous phase [59]. Sodium acetate (AP-10018818, Sinopharm Chemical Reagent Co., Ltd., Shanghai, China) was used in this test since it was the external carbon source added during the anoxic periods of the case studied $[59,60]$. This test was operated at $20^{\circ} \mathrm{C}$ and $10{ }^{\circ} \mathrm{C}$, respectively, and a $\mathrm{pH}$ value of $7.5 \pm 0.1$ with a low concentration of MLVSS, which provided a suitable low OUR that improved the $Y_{\mathrm{H}}$ assessment.

According to the literature [60], the heterotrophic yields can be calculated from the following equation:

$$
\mathrm{OC}=\left(1-Y_{H}\right) \cdot S_{\text {Ace }}
$$

where OC is the accumulated exogenous oxygen consumption, $S_{\text {Ace }}$ is the concentration of the added sodium acetate. The OC in summer and winter was calculated according to the added biodegradable organic substrate concentration, respectively. 


\subsubsection{Heterotrophic Decay Rate $b_{\mathrm{H}}$}

The heterotrophic decay rate, $b_{\mathrm{H}}$, is critical for the prediction of sludge production and oxygen demand [30]. Therefore, it must be determined based on the activated sludge used in the OUR test of $b_{\mathrm{H}}$.

Since heterotrophic bacteria were in the endogenous respiratory stage after $24 \mathrm{~h}$ of aeration, OUR can only be caused by the microbial auto-oxidation. There was a linear relationship between $\ln$ (OUR) and time $t$, the slope of the curve is a negative traditional decay rate which follows the next formula [41]:

$$
\ln (\text { OUR })=-K_{\mathrm{d}} t+\ln \left(f_{v C} K_{\mathrm{d}} X_{0 \mathrm{~B}, \mathrm{H}}\right)
$$

where $f_{\mathrm{VC}}$ is a proportional constant; $\mathrm{K}_{\mathrm{d}}$ is global attenuation coefficient, $\mathrm{X}_{0 \mathrm{~B}, \mathrm{H}}$ is initial concentration of active heterotrophic biomass $(\mathrm{mg} / \mathrm{L})$

The $b_{\mathrm{H}}$ can be calculated from the next equation which is related to $K_{d}$ [30]:

$$
b_{\mathrm{H}}=\frac{K_{d}}{1-Y_{H}\left(1-f_{p}\right)}
$$

For each summer and winter, $1500 \mathrm{~mL}$ activated sludge taken from the CASS system of this WWTP was put in a batch reactor, then washed with the distilled water after $24 \mathrm{~h}$ aeration, and the OUR was further measured for multiple times in 4 days [41]. During the experiments, $\mathrm{pH}$ and temperature were controlled the same as the values in summer and winter, respectively.

\subsubsection{COD Fractionation of Influent}

In ASM1 model, the constituent elements of total COD were presented by equation:

$$
\mathrm{COD}=S_{\mathrm{I}}+S_{\mathrm{S}}+X_{\mathrm{I}}+X_{\mathrm{S}}
$$

where:

$S_{\mathrm{I}}$-soluble inert substrates, $\mathrm{g} \mathrm{O}_{2} \mathrm{~m}^{-3}$;

$S_{\mathrm{S}}$-soluble readily biodegradable substrates, $\mathrm{g}_{2} \mathrm{~m}^{-3}$;

$\mathrm{X}_{\mathrm{I}}$-inert particulate organic material, $\mathrm{g} \mathrm{O}_{2} \mathrm{~m}^{-3}$;

$X_{S}$-particulate slowly biodegradable substrates, $\mathrm{g} \mathrm{O}_{2} \mathrm{~m}^{-3}$;

According to the Equation (4), the influent COD fractions can be divided into the above four components and be used as the influent simulation data for the ASM1 model.

The soluble COD value (SCOD) of sewage is usually defined as the COD through a $0.45 \mu \mathrm{m}$ microfiltration membrane. According to the literature [61], the floc in the zinc sulfate coagulation filtration method has a small adsorption amount to the SCOD, and the supernatant COD is close to the truly solution COD. Therefore, the steps of the physical and chemical separation method to determine the SCOD were as follows: Firstly, $10 \mathrm{~mL}$ of $100 \mathrm{~g} \cdot \mathrm{L}^{-1}$ zinc sulfate was added to $1 \mathrm{~L}$ of the wastewater sample to be tested, and the $\mathrm{pH}$ was adjusted to about 10.5 with $6 \mathrm{~mol} \cdot \mathrm{L}^{-1} \mathrm{NaOH}$ under the rapid stirring of the magnetic stirrer; Secondly, the liquor was mixed at high speed $\left(120 \mathrm{r} \cdot \mathrm{min}^{-1}\right)$ for $1 \mathrm{~min}$ and low speed $\left(60 \mathrm{r} \cdot \mathrm{min}^{-1}\right)$ for $5 \mathrm{~min}$ by magnetic stirrer, and then static settlement for $15 \mathrm{~min}$; At last, conventional disposable filters with pore size of $0.45 \mu \mathrm{m}$ (Durapore ${ }^{\circledR}$ Membrane Filter, polyvinylidene fluoride (PVDF), New York, USA) were used for sequential filtration after sedimentation. The COD value of the filtrate is the wastewater SCOD [36].

The OUR curve of the mixture could be divided into three segments. In $\mathrm{S} 1, \mathrm{t}<\mathrm{t}_{1}$, the OUR value sharply decreased because the substrate was easily biodegradable; in $\mathrm{S} 2, \mathrm{t}_{1}<\mathrm{t}<\mathrm{t}_{2}$, OUR slowly decreases, the rate of which is controlled by the substrate provided by the slow degradation of the substrate $X_{S}$ in the wastewater; in $S 3, t>t_{2}$, OUR is almost constant and is maintained at a relatively low level, which can be considered as the oxygen consumption of endogenous respiration of the original heterotrophic microorgan- 
isms before mixing with wastewater. As a result, the $S_{\mathrm{S}}$ and $X_{\mathrm{S}}$ could be calculated from the partial OUR curves in S1 and S2 individually.

To get a clear description of the OUR curves for COD fractions, before the respiroetric tests, the volume of the wastewater, $V_{\mathrm{W}}$, and the activated sludge, $V_{\mathrm{S}}$, should be determined to get a suitable $\mathrm{F} / \mathrm{M}$ ratio (the ratio between the SCOD of influent value and the MLVSS). The suggested F/M ratio for the OUR tests was between 0.01 and $0.2 \mathrm{mg} C O D / \mathrm{mg}$ VSS [38]. For each season's OUR test, triplicate experiments were performed to get a good repeatability. $S_{S}$ and $X_{S}$ could be calculated by the following equations:

$$
\begin{gathered}
S_{S}=\frac{V_{\mathrm{W}}+V_{\mathrm{S}}}{V_{\mathrm{W}}} \cdot \frac{1}{1-Y_{\mathrm{H}}} \int_{0}^{t_{1}}\left(\mathrm{OUR}_{\text {tot }}-\mathrm{OUR} \mathrm{R}_{\mathrm{X}_{S}}\right) \cdot d t \\
X_{\mathrm{S}}=\frac{V_{\mathrm{W}}+V_{\mathrm{S}}}{V_{\mathrm{W}}} \cdot \frac{1}{1-Y_{\mathrm{H}}} \int_{t_{1}}^{t_{2}}\left(\mathrm{OUR}_{\mathrm{X}_{\mathrm{S}}}-\mathrm{OUR} R_{E R}\right) \cdot d t
\end{gathered}
$$

where $O U R_{\text {tot }}$ is total oxygen uptake rate $\left(\mathrm{mg} /\left(\mathrm{L} \cdot \mathrm{d}^{-1}\right)\right)$, $O U R_{X s}$ is oxygen uptake rate of $X_{S}$ consumption and endogenous respiration $\left(\mathrm{mg} /\left(\mathrm{L} \cdot \mathrm{d}^{-1}\right)\right), O U R_{E R}$ is oxygen uptake rate of endogenous respiration $\left(\mathrm{mg} /\left(\mathrm{L} \cdot \mathrm{d}^{-1}\right)\right)$

\subsection{Model Calibration and Validation Strategy}

In this study, the GPS-X software (Hydromantis Inc., Ontario, Canada) with ASM1 model was used to simulate the CASS system. Two key parameters $\left(Y_{\mathrm{H}}, b_{\mathrm{H}}\right)$ were measured based on the respirometry batch experiment, other model parameters were mainly corrected according to the sensitivity analysis. The input data for the simulations came from the CASS WWTP and comprised the period of June 2018 for the calibration and July 2018 for the validation for summer simulation, December 2018 for calibration and January 2019 for validation for winter simulation, respectively. Table 1 lists the operating parameters and wastewater characteristic values used for model calibration and verification.

The validated model was used for simulation and optimization to achieve complete denitrification in wastewater, thereby providing upgrade solutions to meet TN emission standards and reduce operating costs. Optimization was completed by running multiple simulations on different operating scenarios, such as reducing aeration time and testing different operation modes in the CASS tanks, increasing anoxic time to perform nitrificationdenitrification. The optimized operation strategies were applied to the CASS operation in practice from August 2018 to February 2019, respectively, to acquire the optimized operation data from the WWTP.

\subsection{Sensitivity Analysis}

Sensitivity analysis can assess to what extent the parameters used in model calibration affect the output of the model [62]. Sensitivity analysis before model calibration is necessary to evaluate important parameters [63]. According to EPA guidelines [64], the sensitivity coefficient $\left(S_{i, j}\right)$ is defined as a ratio of the percentage change in the output variable $\left(y_{i}\right)$ to a $10 \%$ change in the input variable $\left(x_{i}\right)$ :

$$
S_{i, j}=\frac{\Delta y_{i} / y_{i}}{\Delta x_{j} / x_{j}}
$$

In this study, all model coefficients (including kinetic coefficients and stoichiometric coefficients) were changed by $10 \%$ in the simulation. The determination of key parameters during calibration depends on the sensitivity of the model output to these parameters. The effect of parameters on the model output can be explained as: $(1)<0.25$ means that the parameter has no significant effect on the model output, (2) $0.25 \leq\left|S_{i, j}\right|<1$ means that the parameter has an effect; (3) $1 \leq\left|S_{i, j}\right|<2$ indicates that the parameters are very influential; (4) $\left|S_{i, j}\right| \geq 2$ indicates that the parameters are extremely influential [65]. 


\subsection{CFD Modelling}

In full-scale WWTPs, submerged agitators are always used to control high-flow mixing, and it is generally known that the single performance parameter thrust $(\mathrm{F})$ is the basis of the design of the agitation system and the positioning principle of a series of agitators [57]. CFD can be used to model the mixer in detail, but it is too complicated to be included in a wide range of plant models, instead, at the same agitators geometrical location, a simile was used to contain the mechanical momentum added by the agitators in the system as the momentum source $\mathrm{M}\left(\mathrm{kg} \cdot \mathrm{m}^{-2} \cdot \mathrm{s}^{-2}\right)$ [66]. The detail description used in this section was referred to the literature [67].

In order to evaluate the effect of the two different installation layouts of the agitators on the fluid dynamics and its influence on the kinetic model, a CFD three-dimensional single-phase method was performed by ANSYS ${ }^{\circledR}$ Academic Research Release 18.0 software (ANSYS, Inc., New York, NY, USA) which was used as the CFD modelling in this study. The different simulations described in this section were run on ANSYS-Fluent against traditional and modified configurations to achieve these goals. The second-order upwind and PRESTO scheme, which was suitable for swirling flow, were used for discrete spatial derivatives and discrete pressure, respectively. The semi-implicit method of pressure link equation (SIMPLE) is used to realize the coupling of speed and pressure. At the beginning of the simulation, the under-relaxation factor is reduced to maintain stability and avoid solution divergence. When the proportional residual continuity drops below $1 \times 10^{-4}$ and the velocity and turbulence drop below $1 \times 10^{-5}$, the solution is considered to be fully converged.

\subsection{High-Throughput 16 S rRNA Gene Sequencing}

In order to reveal the impact of microbial population changes on the performance of the CASS system, activated sludge samples collected in four seasons were selected as samples for $16 \mathrm{~S}$ rRNA gene amplicon sequencing. These samples were processed in order to perform DNA extraction and $16 \mathrm{~S}$ rRNA gene PCR, which was followed by the amplification and purification of PCR products. To extract DNA, $2 \mathrm{~mL}$ sludge sample was mixed with the DNA extraction kit according to the manufacturer's instructions. In order to ensure the accuracy of the extraction, four times of DNA samples were extracted from each sample and then mixed evenly. The DNA extracts were purified and stored at $-20^{\circ} \mathrm{C}$ until the analysis. For PCR amplification, bacterial $16 \mathrm{~S}$ rRNA fragments were amplified by adding different eight-base barcodes to the forward primer (5'-GTGCCAGCMGCCGCGGTAA-3') and reverse primer (5'- GCCAGCMGCCGCGGTAA-3') of each sample.

After PCR amplification of $16 \mathrm{~S}$ rRNA gene, the amplicons were purified using SanPrep DNA gel extraction kit. Before transferring the purified PCR product to the sequencing analysis step, it is quantified. Finally, Shanghai Sangong Biotechnology Co., Ltd. (Shanghai, China) performed high-throughput sequencing on the Illumina sequencing platform

\section{Results and Discussion}

\subsection{Assessment of the CASS Process Performance}

The $\mathrm{NH}_{4}{ }^{+}-\mathrm{N}$ and TN removals by the CASS system showed obvious seasonal changes, with higher nitrification and denitrification capacity in summer while lower in winter (Figure S1). The effluent TN and $\mathrm{NH}_{4}{ }^{+}-\mathrm{N}$ concentrations were $16.8 \pm 2.5 \mathrm{mg} \cdot \mathrm{L}^{-1}$ and $1.25 \pm 0.46$ in summer, respectively, while they were $18.6 \pm 3.5 \mathrm{mg} \cdot \mathrm{L}^{-1}$ and $3.3 \pm 1.5 \mathrm{mg} \cdot \mathrm{L}^{-1}$ respectively, during winter. It should be noted that these $\mathrm{TN}$ values exceeded the discharge limit of $15 \mathrm{mg} \cdot \mathrm{L}^{-1}$ during both summer and winter.

In order to better understand nitrogen transformation characteristics in CASS system in summer and winter, the variations of $\mathrm{NH}_{4}{ }^{+}-\mathrm{N}, \mathrm{NO}_{3}{ }^{-}-\mathrm{N}, \mathrm{TN}$ concentrations and COD in the main CASS reaction zone were analyzed at a time interval of $30 \mathrm{~min}$ and their results are shown in Figure S2. The $\mathrm{NO}_{3}{ }^{-}-\mathrm{N}$ concentration decreased greatly at the beginning of the operation filling phase, even though aeration is turned on at the same time (Figure S2a). This may be mainly due to the dilution of the residual water in the watershed by the 
incoming water. From Figure S2a,b, no matter in summer or winter, during the aeration phase, the nitrification occurred along with the start of aeration. However, there were less oxygen for nitrification process when it was used for COD degradation. The rapid decline of $\mathrm{NH}_{4}{ }^{+}-\mathrm{N}$ occurred obviously when the COD concentration was below $40 \mathrm{mg} \cdot \mathrm{L}^{-1}$. Furthermore, the $\mathrm{NH}_{4}{ }^{+}-\mathrm{N}$ concentration meets the Grade I-A discharge standard of GB 18918-2002 before the end of aeration. As the aeration stopped, the nitrate concentration stabilized, indicating that no denitrification occurred. This may be due to the absence of exogenous carbon during the decanting and settling phases.

The above onsite experimental finding confirmed that the residence time of the predenitrification anoxic zone was too short to meet the discharge standard of nitrogen, and it is necessary to extend the mixing time before aeration to make full use of carbon sources for denitrification and reduce aeration time.

\subsection{Determination of Model Parameters and Influent COD Fractions}

\subsubsection{Heterotrophic Yield $\left(\mathrm{Y}_{\mathrm{H}}\right)$ and Heterotrophic Decay Rate $\left(\mathrm{b}_{\mathrm{H}}\right)$} Heterotrophic Yield $\left(\mathrm{Y}_{\mathrm{H}}\right)$

The actual heterotrophic yield coefficient, $Y_{\mathrm{H}}$ must be known before determining the soluble rapidly biodegradable organic, $S_{S}$. This parameter not only affects the estimation of sludge production and oxygen demand, but also affects the value of other parameters whose determination requires a value for $Y_{\mathrm{H}}$, like $b_{\mathrm{H}}$.

According to the formula (1), OC must be zero when there is no substrate added. The regression lines for the $\mathrm{OC}$ as a function of the start concentration of substrate are therefore forced through $(0,0)$. This procedure means that one yield coefficient is assumed to be valid for the whole area of examined substrate concentrations. The plot of the OC versus the $S_{\text {Ace }}$ enabled the calculation of $\left(1-Y_{\mathrm{H}}\right)$ as the slope (Figure 2a).

Experimental evaluation of model parameters $Y_{\mathrm{H}}$ at different temperatures was shown in Figure 2a. The calculated $Y_{\mathrm{H}}$ in different seasons were 0.663 and 0.615 , respectively, which revealed the calculation of $Y_{\mathrm{H}}$ was a little affected by the temperature, the lower the temperature, the slower the rate of heterotrophic bacteria.

\section{Heterotrophic Decay Rate $\left(b_{\mathrm{H}}\right)$}

The decay coefficient $b_{\mathrm{H}}$ of heterotrophic biomass was determined with linear death according to established procedures [68]. In this study, in the four-day test described in Section 2.3.2, the OUR value was calculated every $12 \mathrm{~h}$, and the graph of $\ln$ (OUR) versus time is shown in Figure $2 \mathrm{~b}$. The calculated $K_{\mathrm{d}}$, the slope of the regressed equation of the curve, were $-0.1988 /$ day and $-0.1526 /$ day, respectively. After substituting $K_{d}$ into Equation (3), the calculated $b_{\mathrm{H}}$ of the activated sludge in summer and winter were $0.51 /$ day and 0.28 /day, respectively.

\subsubsection{COD Fractions of Influent}

In this study, the method described in Section 2.3 was used to analyze the influent wastewater sampled from the CASS system in summer and winter, and the methods for obtaining four COD fractions in wastewater were introduced in detail.

\section{Determination of $S_{\text {I }}$ Fraction}

$S_{\mathrm{I}}$ is defined as soluble inert organic matter in wastewater. After introducing the mixed liquid containing activated sludge and wastewater treatment plant wastewater into the experimental equipment in Section 2.3, the COD value of the wastewater is analyzed every $8 \mathrm{~h}$ during the 48 -h aeration period until the COD is constant. Then, the soluble inert organic matter $S_{I}$ was calculated which were $36.52 \mathrm{mg} \cdot \mathrm{L}^{-1}\left(\mathrm{TCOD}=342.33 \mathrm{mg} \cdot \mathrm{L}^{-1}\right)$ in summer and $29.93 \mathrm{mg} \cdot \mathrm{L}^{-1}\left(\mathrm{TCOD}=447.33 \mathrm{mg} \cdot \mathrm{L}^{-1}\right)$ in winter, respectively (Table 2$)$. From the results of $S_{\mathrm{I}}$, the soluble non-biodegradable substance is a little lower in winter than that in summer. 
(a)

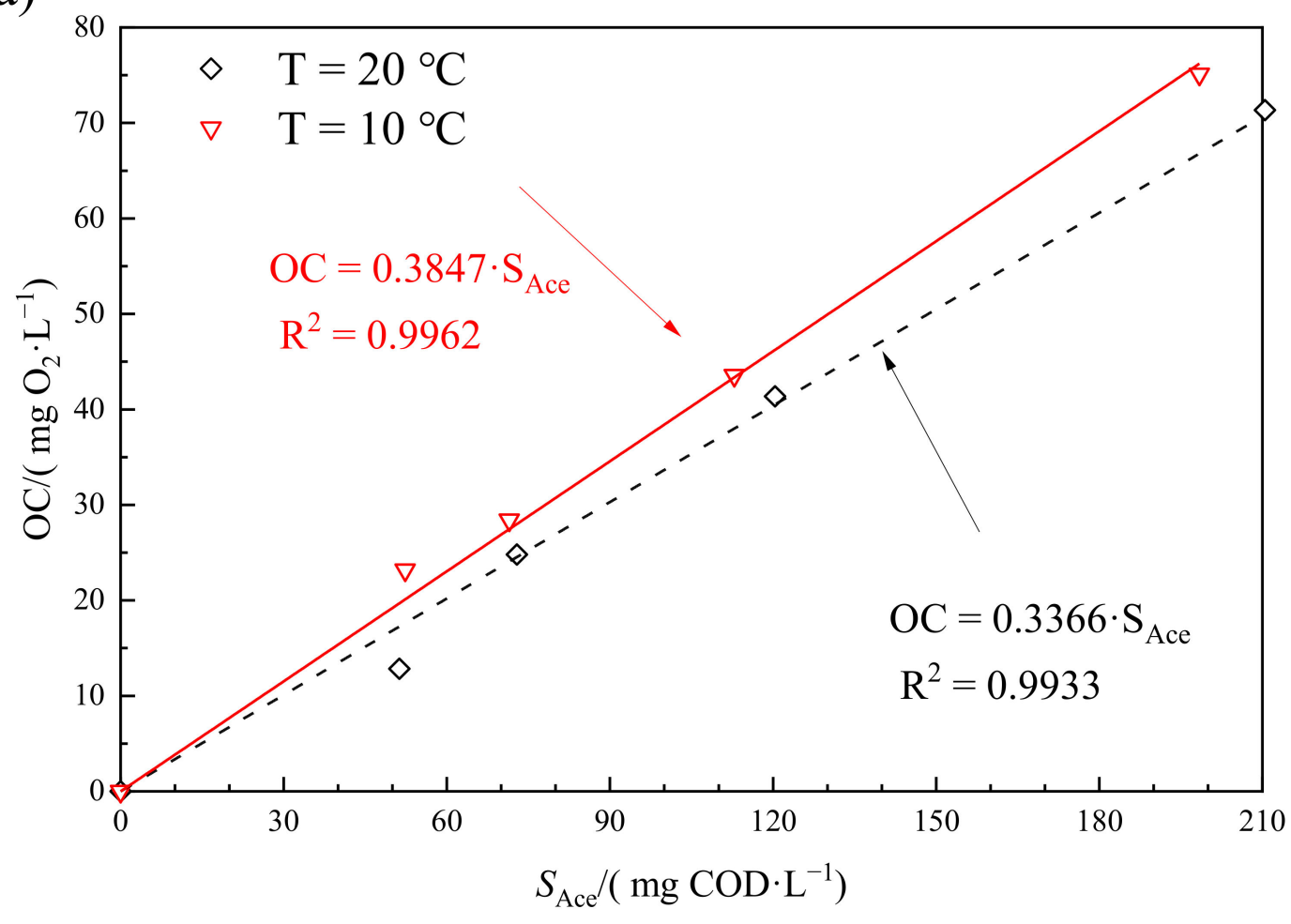

(b)

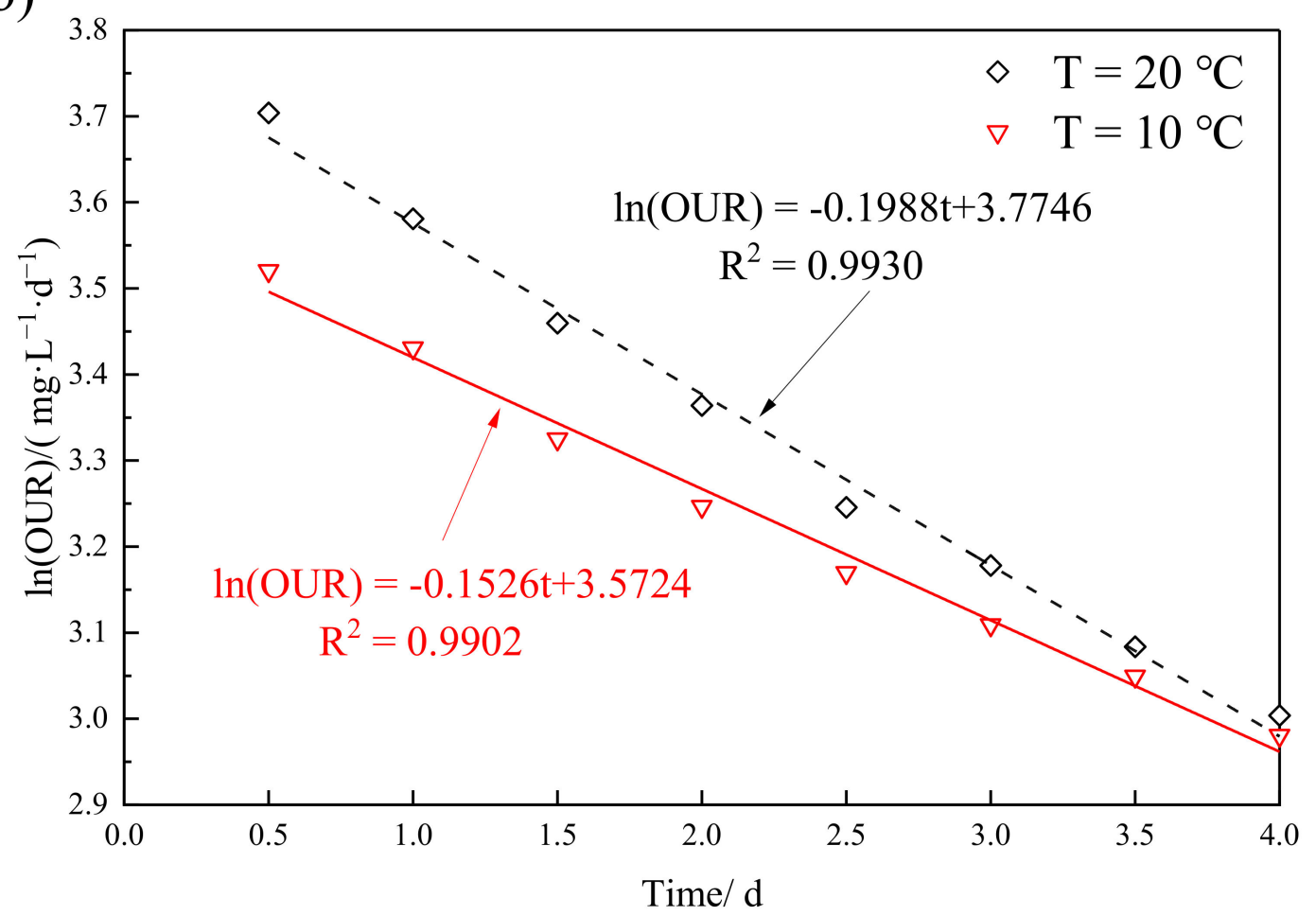

Figure 2. Experimental evaluation of model parameters (a) $Y_{\mathrm{H}}$ and (b) $b_{\mathrm{H}}$ at different temperatures. 
Table 2. COD fractions of the CASS process in summer and winter.

\begin{tabular}{|c|c|c|c|c|c|c|c|c|c|c|c|}
\hline \multirow{3}{*}{ Sources } & \multirow{2}{*}{\multicolumn{2}{|c|}{ Sample ID }} & \multirow{3}{*}{$\begin{array}{l}\text { TCOD } \\
\mathrm{mg} \cdot \mathrm{L}^{-1}\end{array}$} & \multicolumn{8}{|c|}{ COD Fractions } \\
\hline & & & & \multicolumn{2}{|c|}{$s_{\mathrm{S}}$} & \multicolumn{2}{|c|}{$S_{\text {I }}$} & \multicolumn{2}{|c|}{$X_{S}$} & \multicolumn{2}{|c|}{$X_{\mathrm{I}}$} \\
\hline & & & & $\mathrm{mg} \cdot \mathrm{L}^{-1}$ & $\%$ & $\mathrm{mg} \cdot \mathrm{L}^{-1}$ & $\%$ & $\mathrm{mg} \cdot \mathrm{L}^{-1}$ & $\%$ & $\mathrm{mg} \cdot \mathrm{L}^{-1}$ & $\%$ \\
\hline \multirow{8}{*}{$\begin{array}{l}\text { This } \\
\text { study }\end{array}$} & \multirow{4}{*}{ Summer } & 1 & 356.00 & 117.91 & 33.12 & 40.23 & 11.30 & 165.18 & 46.40 & 32.68 & 9.18 \\
\hline & & 2 & 328.00 & 98.99 & 30.18 & 33.75 & 10.29 & 161.70 & 49.30 & 33.55 & 10.23 \\
\hline & & 3 & 343.00 & 110.99 & 32.36 & 35.57 & 10.37 & 168.69 & 49.18 & 27.75 & 8.09 \\
\hline & & Ave. & 342.33 & 109.30 & 31.89 & 36.52 & 10.65 & 165.19 & 48.29 & 31.33 & 9.17 \\
\hline & \multirow{4}{*}{ Winter } & 1 & 440.00 & 93.94 & 21.35 & 26.84 & 6.10 & 261.10 & 59.34 & 58.12 & 13.21 \\
\hline & & 2 & 482.00 & 98.76 & 20.49 & 33.35 & 6.92 & 277.82 & 57.64 & 72.06 & 14.95 \\
\hline & & 3 & 420.00 & 98.95 & 23.56 & 29.61 & 7.05 & 231.76 & 55.18 & 59.68 & 14.21 \\
\hline & & Ave. & 447.33 & 97.22 & 21.80 & 29.93 & 6.69 & 256.89 & 57.39 & 63.29 & 14.12 \\
\hline \multirow{7}{*}{ References } & \multirow{4}{*}{ China } & Beijing & 346.07 & 99.07 & 28.6 & 31.23 & 9.02 & 180.10 & 52.04 & 35.67 & 10.31 \\
\hline & & Shanghai & 342 & 27.70 & 8.1 & 21.55 & 6.3 & 186.39 & 54.5 & 106.36 & 31.1 \\
\hline & & Chongqing & 540 & 51 & 9.4 & 16 & 3.0 & 348 & 64.4 & 126 & 23.3 \\
\hline & \multirow{2}{*}{\multicolumn{2}{|c|}{ Iran }} & 515 & 125 & 24.27 & 40 & 7.77 & 250 & 48.54 & 100 & 19.42 \\
\hline & & Denmark & 400 & 96 & 24 & 32 & 8 & 196 & 49 & 76 & 19 \\
\hline & \multicolumn{2}{|c|}{ Switzerland } & 639 & 23 & 3.6 & 25.56 & 4.0 & 316.31 & 49.5 & 274.13 & 42.9 \\
\hline & \multicolumn{2}{|c|}{ Turkey } & 183 & 18.3 & 10 & 27.45 & 15 & 106.14 & 58 & 31.11 & 17 \\
\hline
\end{tabular}

Determination of $S_{S}$ and $X_{S}$ Fractions

Using basic respirometry, based on the OUR profile obtained at two F/M ratios of 0.18 and $0.15 \mathrm{~g} \mathrm{COD} \cdot \mathrm{g}^{-1} \mathrm{VSS}$ in $20^{\circ} \mathrm{C}$ and $10^{\circ} \mathrm{C}$, respectively, for the composite sample, the important $\mathrm{COD}$ fraction in the wastewater was evaluated experimentally. As shown in Figure S3, the first section was assigned to the degradation of $X_{S}$ and $S_{S}$, both of which were biodegradable. Since $S_{S}$ degrades much faster than $X_{S}$, only $X_{S}$ is present in Section 2 and was further degraded by microorganisms. In the third section, since only endogenous respiration occurred, the values of $S_{S}$ and $X_{S}$ could be calculated and regressed from the OUR local curves in the first two parts, respectively.

Using the values of $Y_{\mathrm{H}}$ calculated from Section 3.2.1, the calculated $S_{\mathrm{S}}$ and $X_{\mathrm{S}}$ values of the influent to the CASS process in the triplicate experiments were listed in Table 2. The results showed that the concentration of $X_{S}$ was higher than $S_{S}$ both in the summer and winter seasons.

\section{Determination of $X_{I}$ Fraction}

According to Equation (4) and the obtained values of $S_{S}, X_{S}, S_{I}$ and TCOD from the previous tests, the computed concentration of $X_{\mathrm{I}}$ were 31.33 and $63.29 \mathrm{mg} C O D \cdot \mathrm{L}^{-1}$ in summer and winter, respectively.

Based on the calculation of the above determined values, Table 2 lists the four COD fractions in different seasons of sewage. These analyzed results demonstrated the following points: (1) Obviously, due to the existence of many particulate fractions, like fine fibers in the CASS influent, the soluble organic substances $\left(S_{\mathrm{S}}\right.$ and $\left.S_{\mathrm{I}}\right)$ accounted for a little proportion of TCOD; (2) There were some differences in COD components from summer and winter seasons which led to different model parameters. Thus, it was quite necessary to analyze the sensitivity of model parameters in different seasons to get accurate simulation results.

Table 2 also shows the comparison of the proportion of COD components between this WWTP and some other cities and countries. This comparison shows that the wastewater components are greatly affected by the structure and quality of the pipe network and living habits, which proves the necessity of dividing COD fractions. As shown in Table 2, the ratio of $S_{S}$ and $S_{I}$ fraction in the studied plant is similar to that in Beijing [69], north of China, while a little higher than that in Shanghai [70] and Chongqing [71], south of China. Compared with other countries, the ratio of $S_{S}$ fraction in the winter influent of this study is similar to that measured by the Iran sewage plant [19], while the proportion in the summer 
influent is slightly higher than that of the Iran sewage plant. The percentage of $X_{\mathrm{I}}$ in the influent of the two seasons is significantly lower than the reported values of Denmark [72], Switzerland [73] and Turkey [74]. In addition, the proportion of $S_{I}$ and $X_{S}$ in the plants during the two seasons are also in the scope of literature reports.

\subsection{Sensitivity Analysis, Calibration and Validation of ASM1 Model}

As shown in Figure S4, in summer season, the first three sequences of the most corresponding significant parameters (absolute value) influencing the effluent $\mathrm{COD}, \mathrm{NH}_{4}{ }^{+}-$ $\mathrm{N}$ and TN were $k_{\mathrm{h}}>\mu_{\mathrm{H}, \max }>K_{\mathrm{S}}, K_{\mathrm{O}, \mathrm{H}}>\mu_{\mathrm{A}, \max }>k_{\mathrm{h}}$, and $k_{\mathrm{h}}>\mu_{\mathrm{H}, \max }>K_{\mathrm{S}}$, while $k_{\mathrm{h}}>K_{\mathrm{X}}>K_{\mathrm{NH}} ; k_{\mathrm{h}}>K_{\mathrm{S}}>b_{\mathrm{A}} ; K_{\mathrm{S}}>K_{\mathrm{X}}>\mu_{\mathrm{H}, \max }$ in winter. As a result, it demonstrated that summer parameters $k_{\mathrm{h}}, \mu_{\mathrm{H}, \max }, K_{\mathrm{S}}, K_{\mathrm{O}, \mathrm{H}}$, and $\mu_{\mathrm{A}, \max }$ have the greatest influence on the established ASM1 model for the CASS WWTP, while parameters $k_{\mathrm{h}}, K_{\mathrm{X}}, K_{\mathrm{NH}}, K_{\mathrm{S}}, b_{\mathrm{A}}$, $\mu_{\mathrm{H}, \max }$ for winter. As the parameter $f_{\mathrm{P}}$ had little influence on the both the outputs of the summer and winter seasons, the default value was used for the model calibration. After that, the above 16 parameters were selected to further calibrate and verify the ASM1 model applied in the CASS system.

After the sensitivity analysis, the model calibration process was a process involving adjusting the model coefficient values.

Therefore, the results produced by the model using these coefficients are in good agreement with a set of measurements. The calibration process requires preliminary guesses and the logical domain of each coefficient. Such initial values are obtained from the literature [28,30]. In this study, the model has been calibrated for COD, $\mathrm{NH}_{4}{ }^{+}-\mathrm{N}$ and TN removals. For two different seasons, nine highly relevant parameters were varied on basis of the causality of the parameters on $\mathrm{COD}, \mathrm{NH}_{4}{ }^{+}-\mathrm{N}$ and $\mathrm{TN}$, respectively. The selection of calibration parameters was based primarily on the results of the sensitivity analysis.

Table 3 shows the kinetic and stoichiometric parameters that are most suitable for the simulated calibration cycle. The simulated and measured values of the basic output variables characterizing the quality of wastewater are shown in Figure 3. Subsequently, validation of the ASM1 model was conducted during a continue month (July in summer 2018 and February in winter 2019, respectively) of the CASS operation period.

Table 3. Kinetic and stoichiometric parameters for ASM1 modelling at $10^{\circ} \mathrm{C}$ and $20^{\circ} \mathrm{C}$ in this study.

\begin{tabular}{|c|c|c|c|c|c|}
\hline \multirow{2}{*}{ Parameters } & \multicolumn{2}{|c|}{ Default Value * } & \multicolumn{2}{|c|}{ Calibration Value } & \multirow{2}{*}{ Units } \\
\hline & $20{ }^{\circ} \mathrm{C}$ & $10{ }^{\circ} \mathrm{C}$ & $20^{\circ} \mathrm{C}$ & $10^{\circ} \mathrm{C}$ & \\
\hline \multicolumn{6}{|c|}{ Stoichiometric parameters } \\
\hline$Y_{\mathrm{A}}$ & 0.24 & 0.24 & 0.24 & 0.24 & g cell COD formed (g N oxidized $)^{-1}$ \\
\hline$f_{\mathrm{P}}$ & 0.08 & 0.08 & 0.08 & 0.08 & dimensionless \\
\hline$i_{\mathrm{XB}}$ & 0.086 & 0.086 & 0.086 & 0.086 & $\mathrm{~g} \mathrm{~N}(\mathrm{~g} \mathrm{COD})^{-1}$ in biomass \\
\hline$i_{X P}$ & 0.06 & 0.06 & 0.06 & 0.06 & $\mathrm{~g} \mathrm{~N}(\mathrm{~g} \text { COD })^{-1}$ in endogenous mass \\
\hline \multicolumn{6}{|c|}{ Kinetic parameters } \\
\hline$\mu_{\mathrm{H}, \max }$ & 6.0 & 3.0 & 9.86 & 3.6 & $\mathrm{~d}^{-1}$ \\
\hline$K_{S}$ & 20.0 & 20.0 & 23.72 & 14.86 & $\mathrm{~g} \mathrm{COD} \mathrm{m}^{-3}$ \\
\hline$K_{\mathrm{O}, \mathrm{H}}$ & 0.20 & 0.20 & 0.19 & 0.20 & $\mathrm{~g} \mathrm{O}_{2} \mathrm{~m}^{-3}$ \\
\hline$K_{\mathrm{NO}}$ & 0.50 & 0.50 & 0.5 & 0.5 & $\mathrm{~g} \mathrm{NO}_{3}-\mathrm{N} \mathrm{m}^{-3}$ \\
\hline$\eta_{\mathrm{g}}$ & 0.8 & 0.8 & 0.8 & 0.8 & dimensionless \\
\hline$\eta_{\mathrm{h}}$ & 0.4 & 0.4 & 0.4 & 0.4 & dimensionless \\
\hline$k_{\mathrm{h}}$ & 3.0 & 1.0 & 4.1 & 1.3 & g slowly biodegradable COD $(\mathrm{g} \text { cell COD } \cdot \mathrm{d})^{-1}$ \\
\hline$K_{X}$ & 0.03 & 0.01 & 0.02 & 0.02 & g slowly biodegradable COD $(\mathrm{g} \text { cell COD })^{-1}$ \\
\hline$\mu_{\mathrm{A}, \max }$ & 0.80 & 0.30 & 0.65 & 0.30 & $\mathrm{~d}^{-1}$ \\
\hline$K_{\mathrm{NH}}$ & 1.0 & 1.0 & 0.95 & 1.0 & $\mathrm{~g} \mathrm{NH}_{3}-\mathrm{N} \mathrm{m}^{-3}$ \\
\hline$k_{\mathrm{a}}$ & 0.08 & 0.04 & 0.08 & 0.04 & $\mathrm{~m}^{3} \mathrm{COD}(\mathrm{g} \cdot \mathrm{d})^{-1}$ \\
\hline$b_{\mathrm{A}}$ & 0.15 & 0.05 & 0.15 & 0.04 & $\mathrm{~d}^{-1}$ \\
\hline$K_{\mathrm{O}, \mathrm{A}}$ & 0.4 & 0.4 & 0.4 & 0.4 & $\mathrm{~g} \mathrm{O}_{2} \mathrm{~m}^{-3}$ \\
\hline
\end{tabular}


Table 3. Cont.

\begin{tabular}{|c|c|c|c|c|c|}
\hline \multirow{2}{*}{ Parameters } & \multicolumn{2}{|c|}{ Default Value * } & \multicolumn{2}{|c|}{ Calibration Value } & \multirow{2}{*}{ Units } \\
\hline & $20^{\circ} \mathrm{C}$ & $10^{\circ} \mathrm{C}$ & $20^{\circ} \mathrm{C}$ & $10^{\circ} \mathrm{C}$ & \\
\hline \multicolumn{6}{|c|}{ Measured parameters ** } \\
\hline$Y_{\mathrm{H}}$ & 0.67 & 0.67 & 0.66 & 0.51 & \multirow{2}{*}{$\begin{array}{l}\mathrm{g} \text { cell COD formed (g COD oxidized })^{-1} \\
\qquad \mathrm{~d}^{-1}\end{array}$} \\
\hline$b_{\mathrm{H}}$ & 0.62 & 0.20 & 0.51 & 0.28 & \\
\hline
\end{tabular}

${ }^{*}$ Default ASM1 value. ${ }^{* *}$ The measured values were not changed during the model calibration.
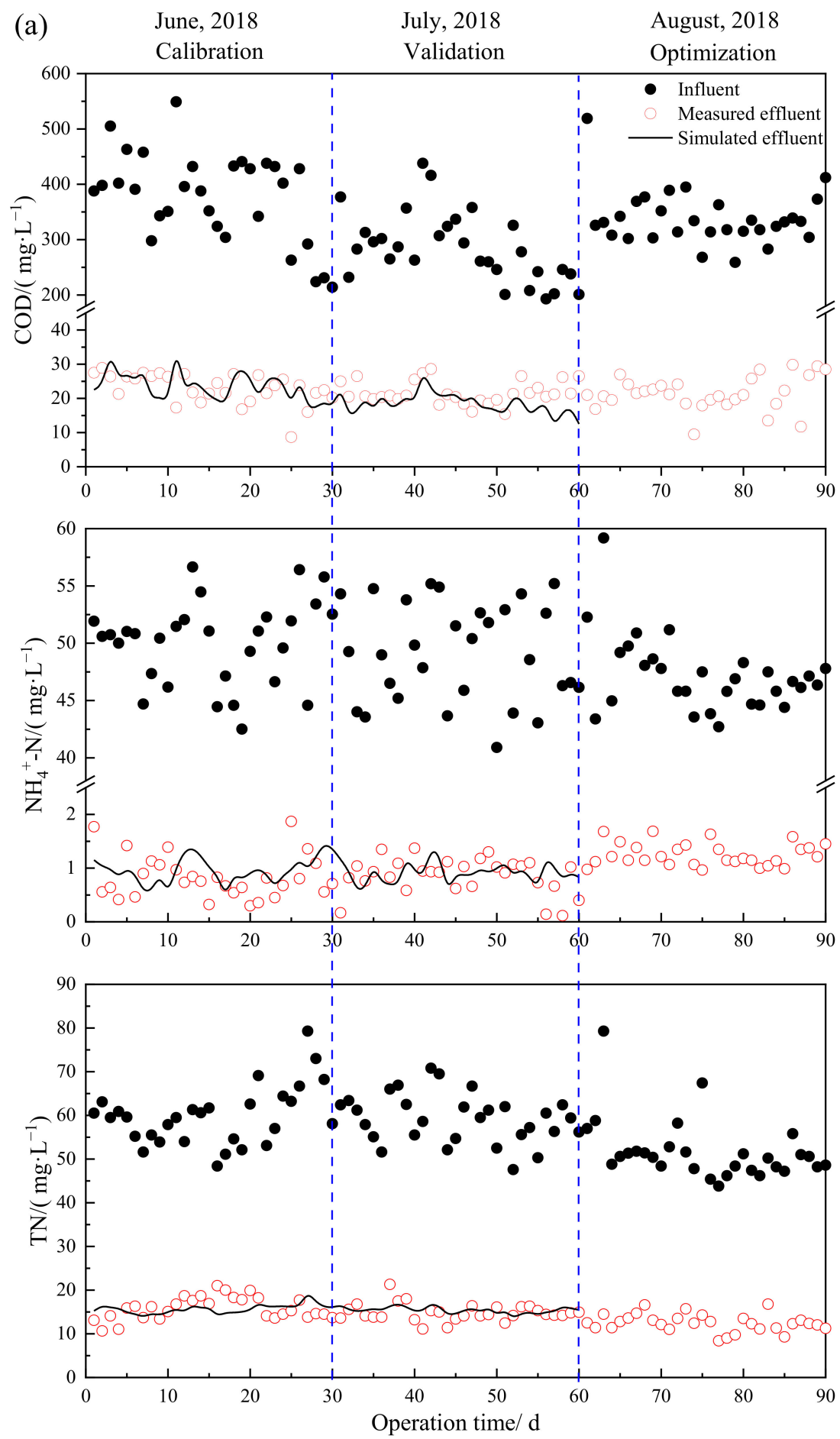

Figure 3. Cont. 

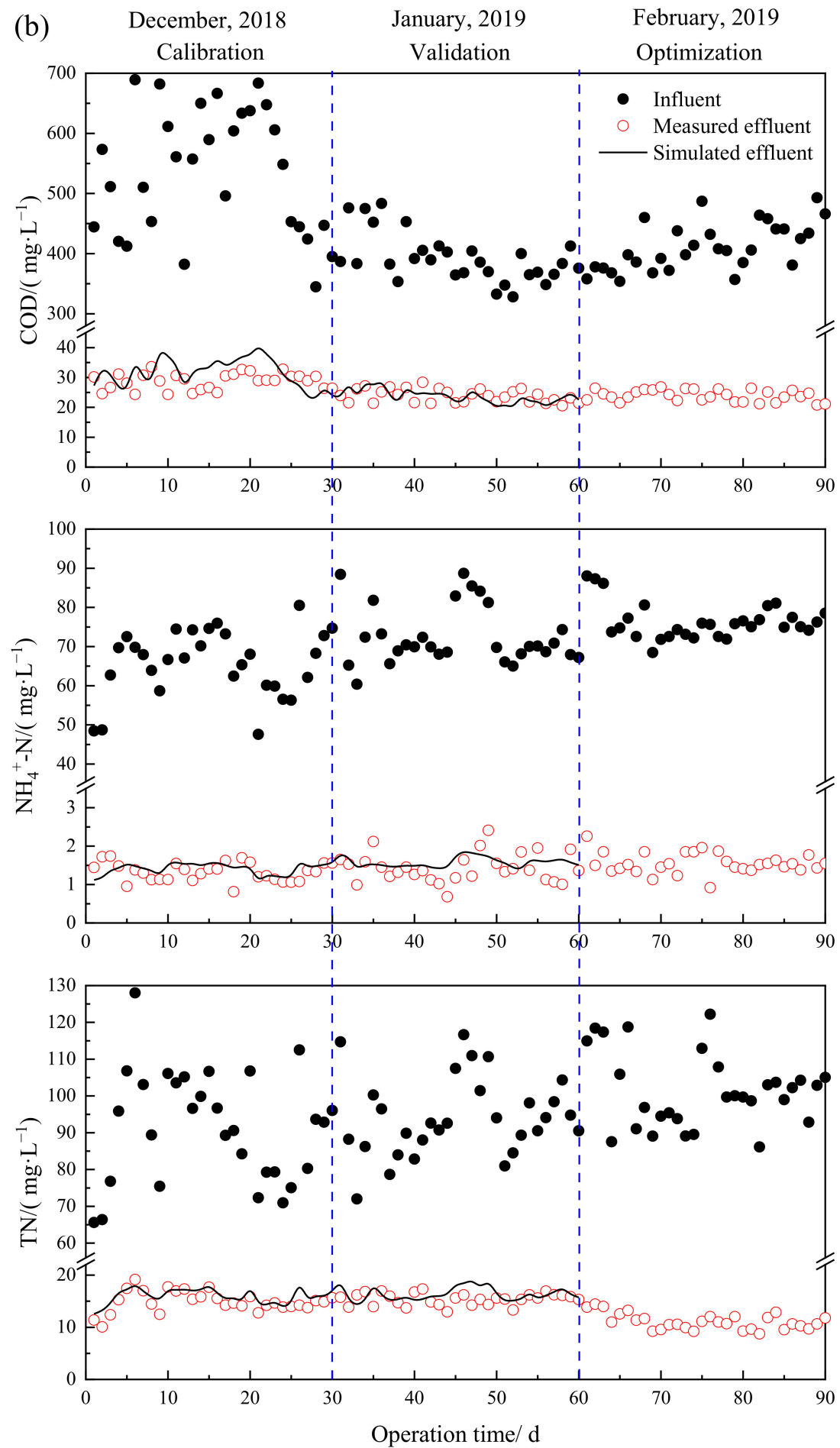

Figure 3. ASM1 simulations, validations and optimizations of the CASS WWTP effluent concentrations in $\mathrm{COD}, \mathrm{NH}_{4}{ }^{+}-\mathrm{N}$ and $\mathrm{TN}$ in (a) summer and (b) winter season.

Regarding the effluent $\mathrm{COD}, \mathrm{NH}_{4}{ }^{+}-\mathrm{N}$ and TN concentrations as output, the ASM1 model has been running according to the real-time characteristics of daily influent wastewater. As shown in Figure 3, the values obtained in the model predictions and actual measurements are in good agreement. In the summer simulation, the average absolute relative error between the measured and simulated values was $18.51 \%, 14.72$ and $13.73 \%$, with respect to the effluent COD, $\mathrm{NH}_{4}{ }^{+}-\mathrm{N}$ and TN, respectively. Similarly, in winter simulation, the average absolute relative error was $15.73 \%, 18.68 \%$ and $9.92 \%$, respectively. Compared with the ideal conditions in the model, this difference may be due to the complex conditions 
of the CASS wastewater treatment plant. However, the predicted COD, $\mathrm{NH}_{4}{ }^{+}-\mathrm{N}$ and TN concentrations are closely related to the measured concentrations. This shows that the mechanism model can be used to effectively simulate the operation of a full-scale sewage treatment plant. Therefore, the mechanism model is used to generate wastewater quality data under different operating conditions for subsequent optimization.

\subsection{Optimization of Nitrification and Denitrification Process}

As the residence time of the pre-denitrification anoxic zone is too short to meet the discharge standard of nitrogen, aerobic tank was used as a large anoxic zone to extend denitrification time to make full use of influent carbon sources. The first plan of the upgrade solution for this CASS WWTP was to add four submersible agitators in the aerobic pool based on the CFD simulation. The operation strategies were optimized based on ASM1 model.

\subsubsection{Optimization of the Flow Field}

The ASM models assume that the bioreactor of the CASS system is a CSTR unit. However, the actual wastewater plant has uneven mixing due to the improper installation of some devices. So before simulating the nutrient removal process, it is necessary to get a uniform flow field with less short flow or dead zone. In this section, two kind of installation locations were simulated in order to improve hydrodynamics (Figure 1). One way is the traditional installation mode, in which four agitators were installed at four corners of the tank with the installation angle of $45^{\circ}$, respectively. The other way is that four agitators were installed at the same side of the tank with different angles $\left(60^{\circ}, 45^{\circ}, 30^{\circ}\right.$ and $90^{\circ}$, respectively). The parameters of the agitators using in the CFD simulation was shown in Table S1.

In order to describe the fluid mechanics in the aeration tank after installing the agitator in more detail, the fluid velocity fields of different configurations are shown in Figure 4.

In Figure 4a, low liquid speed in the tank without agitators installed, and uneven mixing in the flow field is not conducive to mixing contact between pollutants and microorganisms. Figure $4 b, c$ show the fluid velocity field of the traditional and novel installation modes of the agitators in the bioreactor of the CASS system. Both modes can realize a good mix of pollutants with microorganisms. However, the flow velocity of the traditional mode is much larger than that of the novel mode. In addition, the larger agitation speed will cause oxygen to enter the wastewater body, which is not conducive to denitrification process. From this perspective, the novel mode is recommended in the upgrading of this wastewater treatment.

\subsubsection{Optimization of Operation Strategies}

The obtained ASM1 was used to optimize operation conditions of the CASS process in the WWTP. In order to accurately control the effluent quality of pollutants and save energy consumption, six cycle operation scenarios (Figure 5) were evaluated to investigate the performance of CASS among various periods of filling, reaction (including mixing and aeration), and settling phases in the batch cycle time with respect to summer and winter, respectively. The influent characteristics were kept the same as Table 1. 

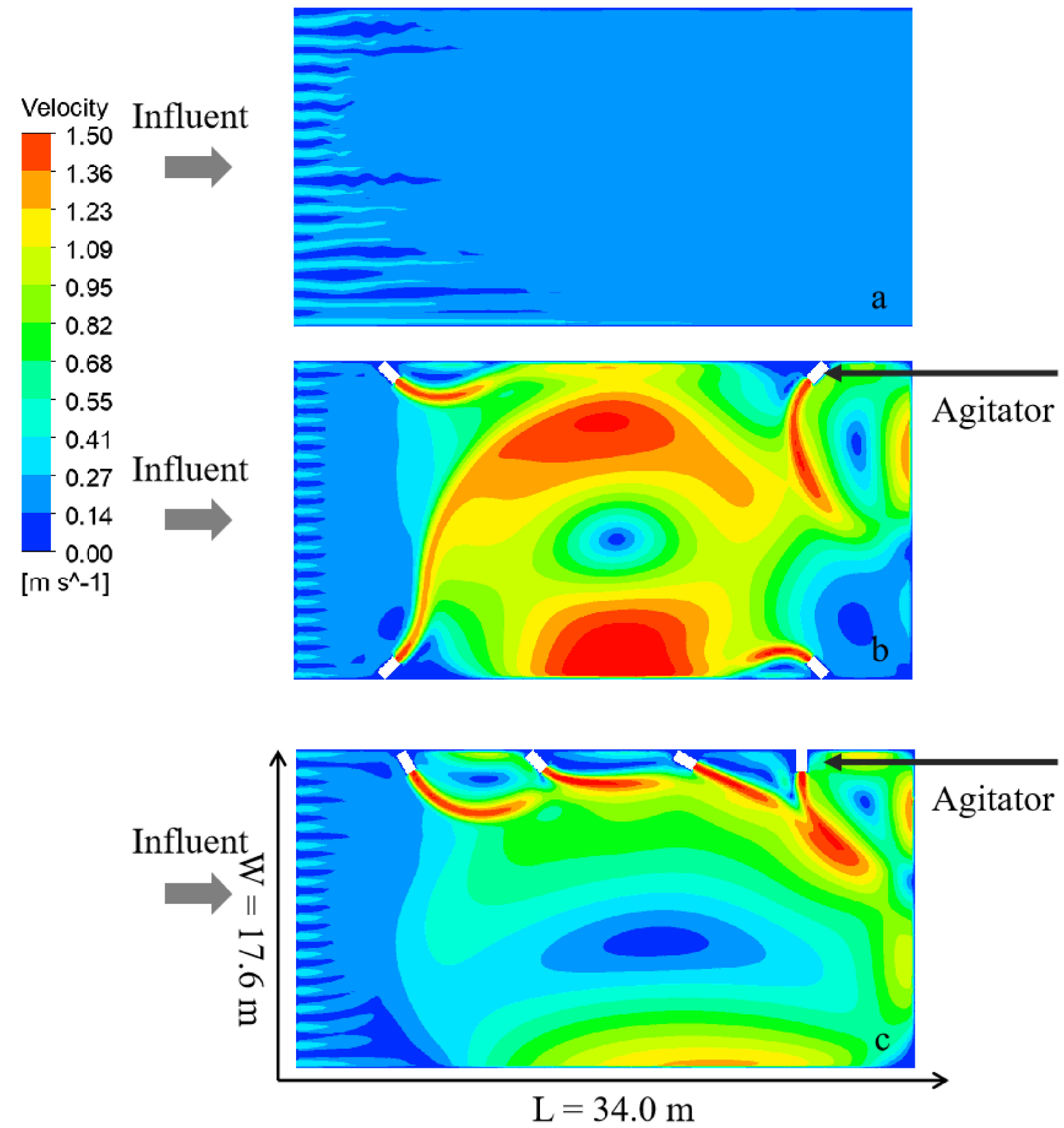

Figure 4. Fluid velocity field in aerobic tank of the CASS system: (a) No agitators installed; (b) Traditional installation mode; (c) Novel installation mode. 


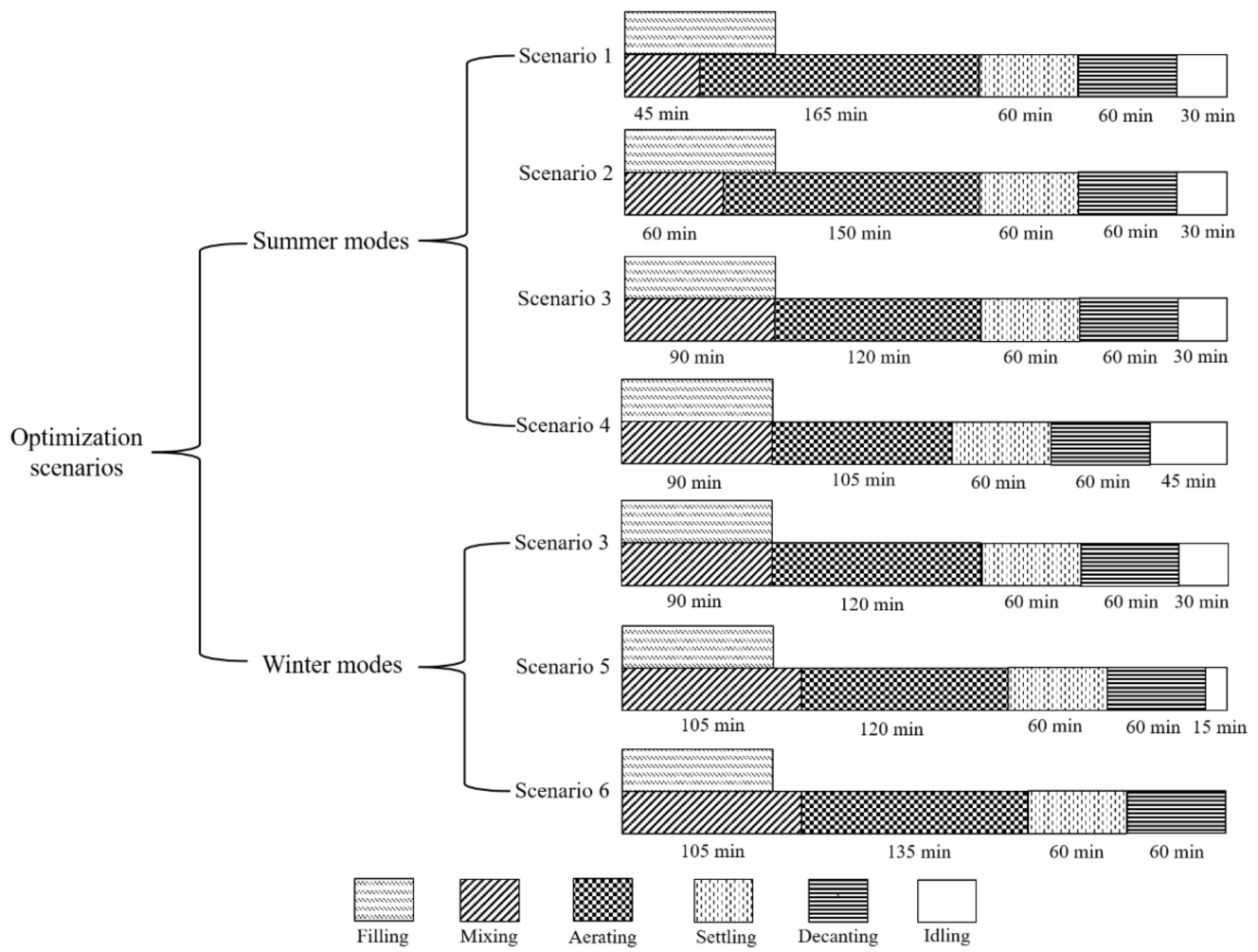

Figure 5. The schematic of season cycle operation strategies to be optimized.

During filling, the influent wastewater is mixed with the biomass left in the tank in the previous cycle. During the mixing and filling process, bacteria will biodegrade organic matter and use residual oxygen or other electron acceptors, such as $\mathrm{NO}_{3}{ }^{-}-\mathrm{N}$. The purpose of the optimization is to reduce the nitrate in the wastewater through the biological denitrification process to convert the nitrate in the wastewater into nitrogen. Table 4 summarizes the results of the summer and winter operation schemes 1 to 6 . In summer scenarios, the TN concentration in effluent decreased with the increase of the mixing time. Only Scenario 3 was suggested, which can meet with the Grade I-A requirements of the discharge standard GB18918-2002. As for Scenario 4, the effluent $\mathrm{NH}_{4}{ }^{+}-\mathrm{N}\left(2.56 \mathrm{mg} \cdot \mathrm{L}^{-1}\right)$ increased due to the shorter of aeration time, and the TN in the effluent $\left(15.69 \mathrm{mg} \cdot \mathrm{L}^{-1}\right)$ did not meet with Grade I-A standard of GB18918-2002. In winter mode, because of the difference of influent characteristics and water temperature, the COD and TN concentrations in scenario 3 can no longer meet the discharge standard. As the stirring and aeration time was prolonged, the concentration in effluent reduced. Scenario 6 was recommended for the winter operation.

Table 4. Simulation results of multiple cycle operational scenarios in this study.

\begin{tabular}{|c|c|c|c|c|c|c|c|c|}
\hline \multirow{2}{*}{\multicolumn{2}{|c|}{ Scenarios }} & \multicolumn{3}{|c|}{ Effluent Quality/(mg. $\left.\mathrm{L}^{-1}\right)$} & \multicolumn{2}{|c|}{ Removal $/ \%$} & \multicolumn{2}{|c|}{ CASS Tank } \\
\hline & & COD & $\mathrm{NH}_{4}{ }^{+}-\mathrm{N}$ & TN & Nitrification & Denitrification & MLSS $\mathbf{m g} \cdot \mathrm{L}^{-1}$ & MLVSS $\mathrm{mg} \cdot \mathrm{L}^{-1}$ \\
\hline \multirow{4}{*}{$\begin{array}{l}\text { Summer } \\
\text { modes }\end{array}$} & 1 & 34.29 & 1.47 & 21.68 & 96.96 & 61.94 & 3250 & 2215 \\
\hline & 2 & 31.76 & 2.17 & 19.76 & 95.52 & 65.32 & 3560 & 2330 \\
\hline & 3 & 24.07 & 1.23 & 14.56 & 97.46 & 74.44 & 3910 & 2850 \\
\hline & 4 & 26.84 & 2.56 & 15.69 & 94.71 & 72.46 & 3780 & 2470 \\
\hline \multirow{3}{*}{$\begin{array}{l}\text { Winter } \\
\text { modes }\end{array}$} & 3 & 66.89 & 4.78 & 16.74 & 91.90 & 81.54 & 4200 & 2660 \\
\hline & 5 & 50.08 & 5.24 & 14.84 & 92.72 & 83.64 & 4520 & 3130 \\
\hline & 6 & 38.54 & 3.27 & 14.17 & 95.52 & 84.38 & 4680 & 3090 \\
\hline
\end{tabular}

$\begin{array}{llll}\text { Grade I-A of } & 50 & 5(8)^{*} & 15\end{array}$

${ }^{*}$ Limits of $\mathrm{NH}_{4}{ }^{+} \mathrm{N}$ concentration in effluent are $5 \mathrm{mg} \cdot \mathrm{L}^{-1}$ at water temperature $>12{ }^{\circ} \mathrm{C}$ and $8 \mathrm{mg} \cdot \mathrm{L}^{-1}$ at water temperature $<12{ }^{\circ} \mathrm{C}$, respectively. 


\subsection{Treatment Performance and Energy Consumption after Upgrading WWTP}

\subsubsection{Treatment Performance}

According to the optimized scenarios for summer and winter, the WWTP in August 2018 and February 2019, respectively, was operated in accordance with the strategies, and the actual treatment performance was shown in Figure 3. The effluent quality of COD, $\mathrm{NH}_{4}{ }^{+}-\mathrm{N}$ and TN all met the discharge standard of Grade I-A. After optimization of the cycle operation time, it could be concluded that the ASM1 model can provide improvement measures for wastewater treatment plant accurately and efficiently.

\subsubsection{Energy Consumption}

The total energy consumption for wastewater treatment before and after upgrade of the WWTP is shown in Figure S5. In summer, after applying the scenario 3, the energy consumption decreased from 0.40 to $0.30 \mathrm{~kW} \cdot \mathrm{h} \cdot \mathrm{m}^{-3}$, which reduced energy consumption by $25 \%$. In winter, the energy consumption was reduced by $16.67 \%$ from 0.42 to $0.35 \mathrm{~kW} \cdot \mathrm{h} \cdot \mathrm{m}^{-3}$ after applying the Scenario 6. The reduction of energy consumption in both summer and winter contributed to the reduction of the time of aeration. In a word, both the optimized scenarios not only improved the nitrogen removal efficiency, but also decreased the energy consumption on the premise of ensuring the effluent quality reaches the discharge standard.

\subsection{Evolution of Microbial Community in CASS}

The 16S rRNA gene pyrosequencing was performed to characterize the microbial communities' evolution before and after WWTP modification in summer and winter, with four samples being obtained from the treatment plant. Table 5 shows the alpha index of microbial diversity.

Table 5. Alpha index of microbial diversity before and after WWTP modification in summer and winter.

\begin{tabular}{cccccc}
\hline Scheme & $\begin{array}{c}\text { Shannon } \\
\text { Index }\end{array}$ & ACE Index & Chao Index & $\begin{array}{c}\text { Coverage } \\
\text { Index }\end{array}$ & $\begin{array}{c}\text { Simpson } \\
\text { Index }\end{array}$ \\
\hline $\begin{array}{c}\text { Summer } \\
\text { original }\end{array}$ & 5.0814 & 2504.50 & 2522.75 & 0.9913 & 0.02518 \\
$\begin{array}{c}\text { Summer } \\
\text { optimized }\end{array}$ & 5.4416 & 2771.51 & 2746.00 & 0.9910 & 0.02301 \\
$\begin{array}{c}\text { Winter } \\
\text { original } \\
\text { Winter } \\
\text { optimized }\end{array}$ & 5.1272 & 2669.78 & 2835.68 & 0.9606 & 0.02297 \\
\hline
\end{tabular}

The results of the bacteria at the phylum level for each sample are shown in Figure 6a. According to Figure 6a, the predominant phyla in four samples were Proteobacteria, Bacteroidetes and Firmicutes. In summer, before the upgrading, the relative abundances of Proteobacteria and Bacteroidetes in the microbial community accounted for $44.82 \%$ and $24.08 \%$, respectively, similar to the results of bacterial communities in full-scale WWTPs [51,75], and the relative abundances of Firmicutes contained a small amount (5.61\%). After upgrading, though some increase in Proteobacteria (53.85\%) and decrease in Bacteroidetes (21.44\%) occurred, they still dominated in bacterial community. A certain amount of Verrucomicrobia (5.79\%) appeared in summer. After the upgrading of the plant, the microbial biodiversity of the activated sludge further increased, the dominant population also increased, the overall structure became more balanced. There was a certain similarity in winter sludge community structure change. The relative abundance of Proteobacteria, which have both denitrification and phosphorus removal capabilities, increased $5.66 \%$ (from $53.10 \%$ to $56.02 \%$ ) after winter upgrading. The relative abundance of Acidobacteria, Firmicutes and Acinobacteria increased 2.24\%, 2.92\% and $2.15 \%$, respectively. The nitrification capacity of the system has been improved, which is reflected in the decrease in $\mathrm{NH}_{4}{ }^{+}-\mathrm{N}$ concentration in the effluent. 
(a)

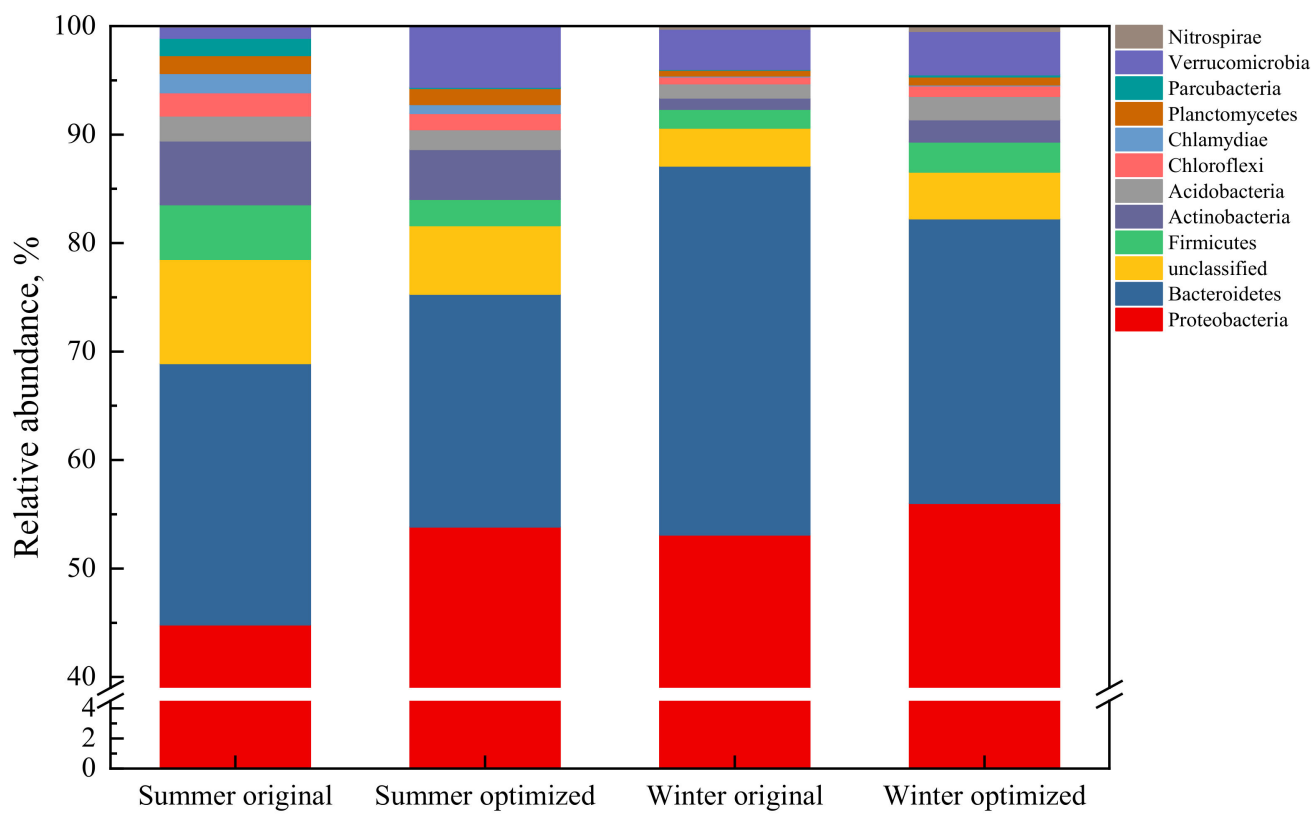

(b)

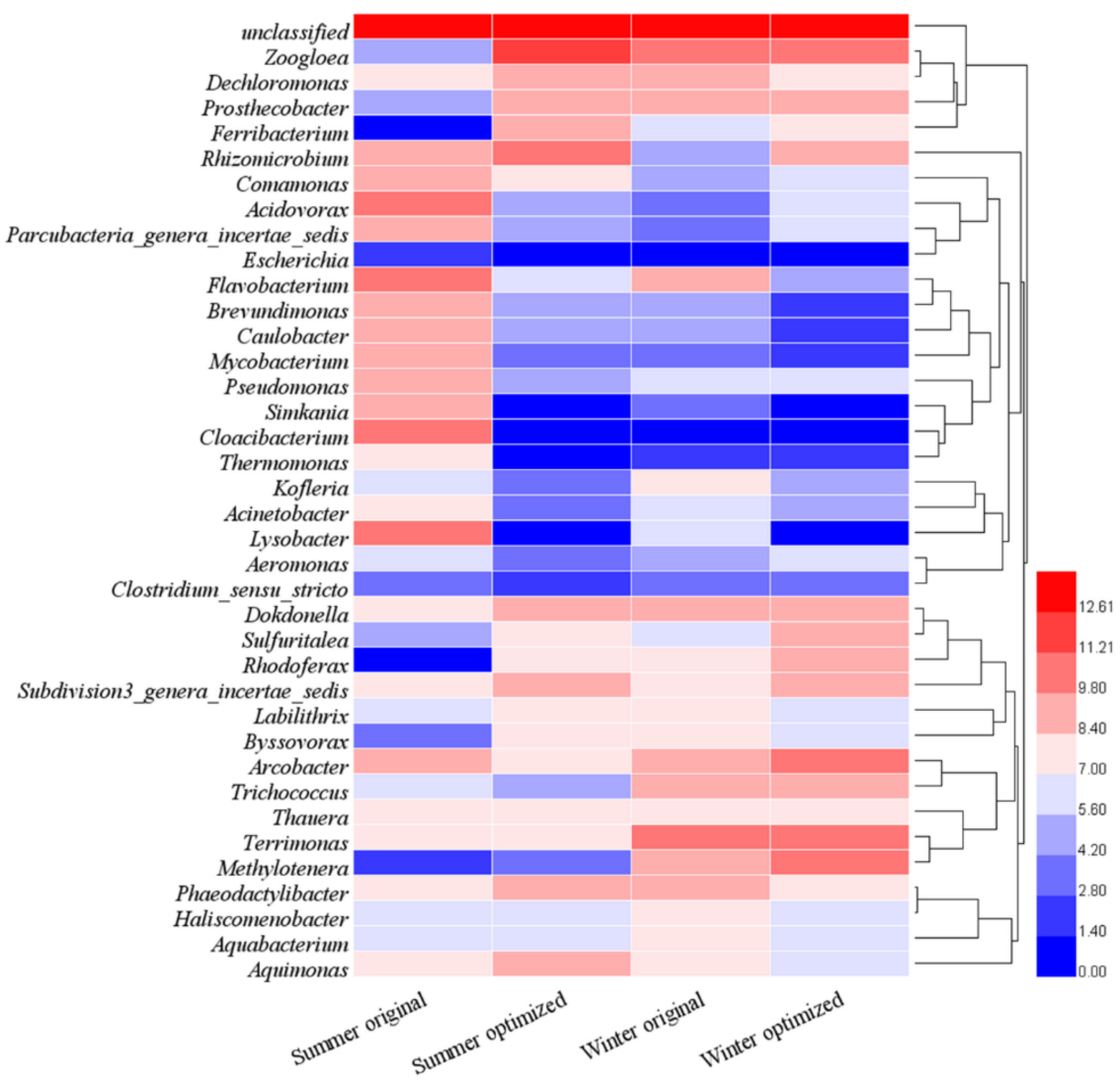

Figure 6. The relative abundance of bacterial communities at the (a) phylum level and (b) genus level (based on the log2 transformed) before and after the upgrading CASS process in different seasons. 
Comparing summer with winter, after upgrading, the relative abundance of Proteobacteria increased from $53.85 \%$ to $56.02 \%$, which shows that the decrease in water temperature has caused the emergence of more Proteobacteria in the system that can maintain stable operation of the activated sludge system and release phosphorus and denitrification in the anaerobic and anoxic phases, respectively..

At the genus level (Figure 6b), the genera related to denitrification mainly include Methylotenera, Zoogloea, Dechloromonas, Arcobacter, Thauera, and Pseudomonas. In winter, Methylotenera (8.96\% to $12.94 \%)$, Zoogloea (8.66\% to $8.74 \%)$, Dechloromonas $(8.15 \%$ to $7.63 \%)$, Arcobacter (8.31\% to $9.43 \%$ ), Thauera (7.11\% to 7.66\%), and Pseudomonas (5.43\% to 5.67\%) in the CASS system accounted for $52.06 \%$ of the known microbial genus. These results clearly showed that the denitrifying bacteria in the system increased significantly resulting in changes of $\mu_{\mathrm{H} \text {,max }}$ and $K_{\mathrm{S}}$ listed in Table 3 , after the sewage plant was upgraded and stable operation in low temperature.

\section{Conclusions}

In this study, successfully modelling and its application was performed for the fullscale CASS WWTP in summer and winter season of North China. The main conclusions are made as following:

(1) The solution based on modelling of ASM1 and CFD was successfully applied for upgrading the full-scale CASS process WWTP, which resulted in not only the effluent COD, $\mathrm{NH}_{4}{ }^{+}-\mathrm{N}$ and $\mathrm{TN}$ concentrations meeting with the discharge standard of Grade I-A, but also reducing energy consumption of the WWTP from $16.67 \%$ to $25 \%$.

(2) Influent COD fractions and their difference in summer and winter were determined, and the key characteristic parameters $\left(Y_{\mathrm{H}}\right.$ and $\left.b_{\mathrm{H}}\right)$ of the activated sludge were determined through the respirometry at temperatures of $10^{\circ} \mathrm{C}$ and $20{ }^{\circ} \mathrm{C}$, respectively. The agitators' installation layout in the bioreactor of the CASS process was optimized through CFD simulation. These results guarantee the long-term continuation of the ASM1 modelling simulation validity for optimizing operational scenarios of the CASS process in summer and winter.

(3) The microbial biodiversity of the activated sludge is increased after upgrading, and the relative abundance of the denitrifying bacteria increased significantly, revealing the microbiological significance of the biological reaction kinetic parameters, like $\mu_{\mathrm{H}, \mathrm{max}}, K_{\mathrm{S}}$, of the ASM1 model.

Supplementary Materials: The following are available online at https://www.mdpi.com/2227 $-9717 / 9 / 3 / 527 / s 1$, Figure S1: Historical operation data of sewage treatment plants in the past year (2017-03-01 to 2018-03-01), Figure S2: Typical profiles of $\mathrm{NH}_{4}{ }^{+}-\mathrm{N}, \mathrm{NO}_{3}^{-}-\mathrm{N}, \mathrm{TN}$ and COD in the main reaction zone during one cycle in continuous feeding CASS. ((a) Summer original, MLSS $=5745 \mathrm{mg} / \mathrm{L}, \mathrm{T}=21^{\circ} \mathrm{C}, 03 / 06 / 2018 ;(b)$ Winter original, MLSS $=6589 \mathrm{mg} / \mathrm{L}, \mathrm{T}=10{ }^{\circ} \mathrm{C}$, 5/12/2018; (c) Summer optimized, MLSS = $3261 \mathrm{mg} / \mathrm{L}, \mathrm{T}=23^{\circ} \mathrm{C}, 19 / 07 / 2018$; (d) Winter optimized, MLSS $\left.=4719 \mathrm{mg} / \mathrm{L}, \mathrm{T}=9^{\circ} \mathrm{C}, 15 / 02 / 2019\right)$. Symbols: $\mathrm{NH}_{4}{ }^{+}-\mathrm{N}(\star), \mathrm{NO}_{3}{ }^{-}-\mathrm{N}(\Delta), \mathrm{TN}(\triangle)$ and COD $(\diamond)$, Figure S3: OUR curves of CASS influent of three repeated experiments in $20^{\circ} \mathrm{C}$ and $10{ }^{\circ} \mathrm{C}$, Figure S4: Sensitivity analysis of the ASM1 model parameters on the model outputs, Figure S5: Energy consumption comparison of per volume of treated wastewater $\left(\mathrm{E}_{\mathrm{V}}\right)(\mathrm{a})$ and per unit mass of TN removal $\left(\mathrm{E}_{\mathrm{N}}\right)(\mathrm{b})$ between the original condition and ASM1 optimized condition in summer and winter season. Table S1: The parameters and installation modes of the agigators used in the CFD simulation.

Author Contributions: Conceptualization, M.L.; methodology, M.C.; software, M.L.; validation, D.Y., and J.Z.; formal analysis, M.C.; investigation, M.L., R.Q., D.Y., M.Y., and J.Z., H.D.; resources, M.L.; data curation, M.L., H.D.; writing—original draft preparation, M.L.; writing—review and editing, Y.W.; visualization, M.L.; supervision, Y.W.; project administration, Y.W.; funding acquisition, Y.W. All authors have read and agreed to the published version of the manuscript.

Funding: This work was supported by the Major Science and Technology Program for Water Pollution Control and Treatment (2017ZX07102; 2015ZX07203-005), the Joint Research Program of National 
Natural Science Foundation of China and National Science Foundation of Sri Lanka (NSFC-NSF SL) (21861142020), Program of China-Sri Lanka Joint Center for Water Technology Research and Demonstration by the CAS.

Institutional Review Board Statement: Not applicable.

Informed Consent Statement: Not applicable.

Data Availability Statement: Not applicable.

Conflicts of Interest: The authors declare no conflict of interest.

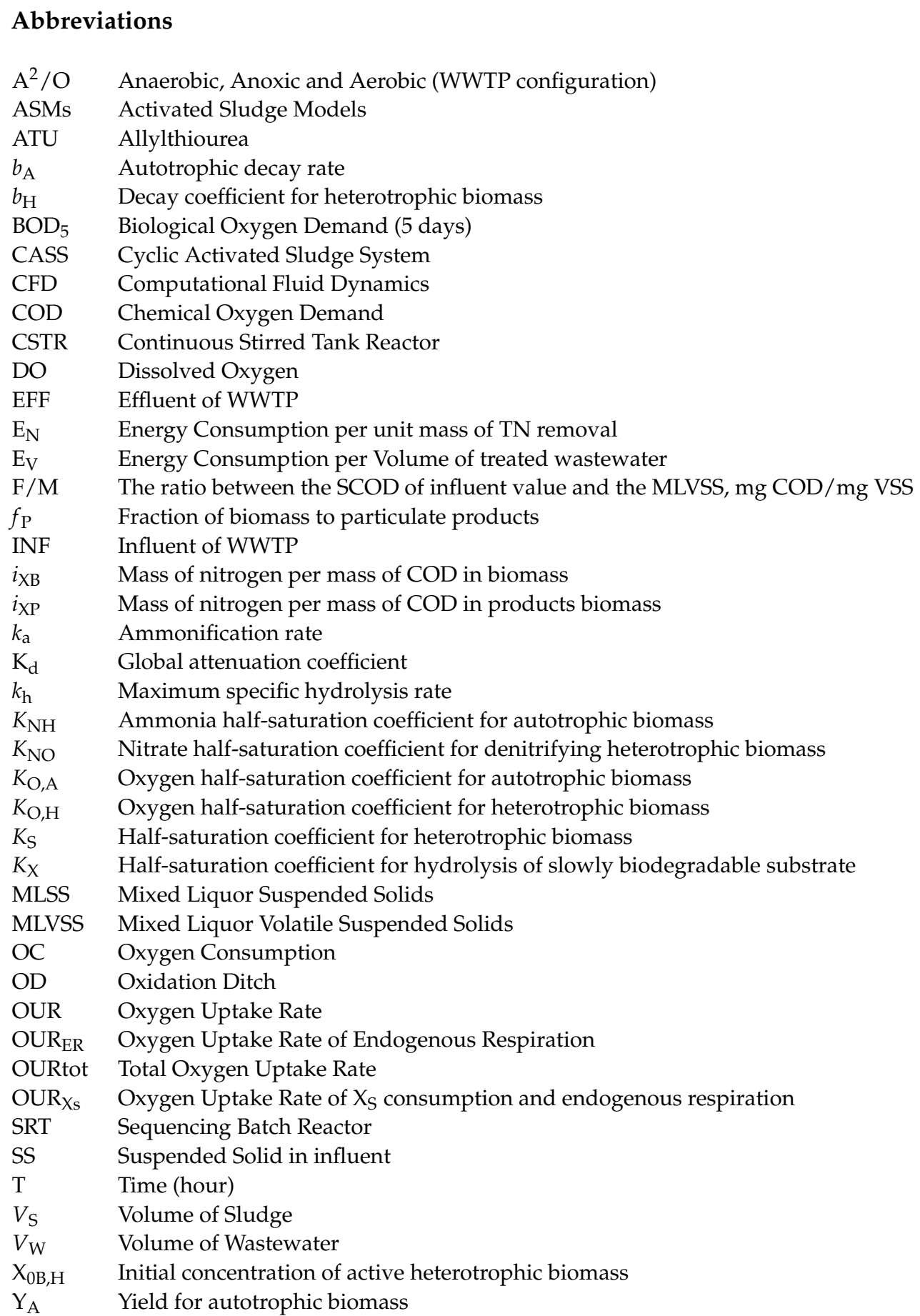




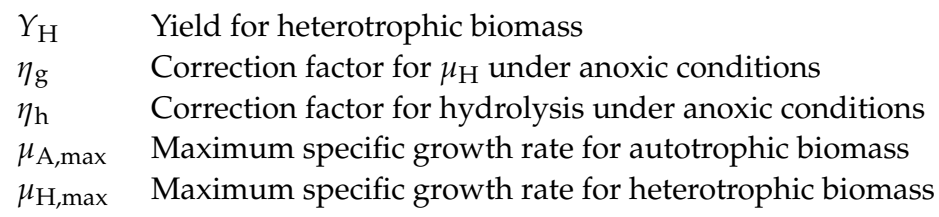

\section{References}

1. WWAP; UNESCO. The United Nations World Water Development Report 2019: Leaving No One behind. 2019. Available online: http:/ / www.unwater.org/publications/world-water-development-report-2019/ (accessed on 18 May 2019).

2. Wang, Q.; Yang, Z. Industrial water pollution, water environment treatment, and health risks in China. Environ. Pollut. 2016, 218, 358-365. [CrossRef]

3. International Water Association (IWA). Wastewater Report 2018: The Reuse Opportunities; International Water Association: London, UK, 2018.

4. Young, J. Global wastewater market challenges. World Pumps 2013, 2013, 22-24. [CrossRef]

5. Shen, Y.; Linville, J.L.; Urgun-Demirtas, M.; Mintz, M.M.; Snyder, S.W. An overview of biogas production and utilization at full-scale wastewater treatment plants (WWTPs) in the United States: Challenges and opportunities towards energy-neutral WWTPs. Renew. Sust. Energy Rev. 2015, 50, 346-362. [CrossRef]

6. Bastian, R.; Cuttica, J.; Fillmore, L.; Hedman, B.; Hornback, C.; Levy, D.; Moskal, J. Opportunities for Combined Heat and Power at Wastewater Treatment Facilities: Market Analysis and Lessons from the Field Combined Heat and Power Partnership; Water Environment Federation: Alexandria, VA, USA, 2011.

7. China State Council, Action Plan for Water Pollution Prevention and Control. 2015. Available online: http://www.gov.cn/ zhengce/content/2015-04/16/content_9613.htm (accessed on 11 September 2015). (In Chinese)

8. Ministry of Environmental Protection. China Environmental Status Bulletin; Ministry of Environmental Protection: Beijing, China, 2018. (In Chinese)

9. National Bureau of Statistics. China Urban Construction Statistics Yearbook; Ministry of Environmental Protection: Beijing, China, 2018. (In Chinese)

10. Zhang, X.Z.; Dai, X.H.; Tang, J.G.; Xie, H. Design of biological process control system and estimation of its energy-saving \& cost-reducing. Chin. Water Wastewater 2019, 35, 77-82.

11. Cao, J.; Pang, Y.M. Application of modified two stage activated sludge process in upgrading and reconstruction of wastewater treatment plant. Ind. Water Treat. 2019, 39, 107-110.

12. Winkler, S.; Gasser, M.; Schattle, W.; Kremmel, D.; Kletzmayr, P.; Matsche, N. Upgrading of wastewater treatment plants for nutrient removal under optimal use of existing structures. Water Sci. Technol. 2008, 57, 1437-1443. [CrossRef] [PubMed]

13. Crini, G.; Eric, L. Advantages and disadvantages of techniques used for wastewater treatment. Environ. Chem. Lett. 2018, 17, 145-155. [CrossRef]

14. Castellet, L.; Molinos-Senante, M. Efficiency assessment of wastewater treatment plants: A data envelopment analysis approach integrating technical, economic, and environmental issues. J. Environ. Manag. 2016, 167, 160-166. [CrossRef]

15. Saleh, I.A.; Zouari, N.; Al-Ghouti, M.A. Removal of pesticides from water and wastewater: Chemical, physical and biological treatment approaches. Environ. Technol. Innov. 2020, 19, 101026. [CrossRef]

16. Shahryar, J. Cost estimation and economical evaluation of three configurations of activated sludge process for a wastewater treatment plant (WWTP) using simulation. Appl. Water Sci. 2017, 7, 2513-2521.

17. Darban, A.K.; Shahedi, A.; Taghipour, F.; Jamshidi-Zanjani, A. A review on industrial wastewater treatment via electrocoagulation processes. Curr. Opin. Electrochem. 2020, 22, 154-169.

18. Benedetti, L.; Bixio, D.; Vanrolleghem, P.A. Assessment of WWTP design and upgrade options: Balancing costs and risks of standards' exceedance. Water Sci. Technol. 2006, 54, 371-378. [CrossRef]

19. Roohian, H.; Mehranbod, N. Investigation of bio-augmentation of overloaded activated sludge plant operation by computer simulation. Comput. Chem. Eng. 2017, 104, 11-24. [CrossRef]

20. Kirchem, D.; Lynch, M.Á.; Bertsch, V.; Casey, E. Modelling demand response with process models and energy systems models: Potential applications for wastewater treatment within the energy-water nexus. Appl. Energy 2020, 260, 114321. [CrossRef]

21. Mo, J.H.; Yang, Q.; Zhang, N.; Zhang, W.X.; Zheng, Y.; Zhang, Z.E. A review on agro-industrial waste (AIW) derived adsorbents for water and wastewater treatment. J. Environ. Manag. 2018, 227, 395-405. [CrossRef]

22. Kirchem, D.; Lynch, M.; Bertsch, V.; Casey, E. Market Effects of Industrial Demand Response and Flexibility Potential from Wastewater Treatment Facilities 2018. In Proceedings of the 15th International Conference on the European Energy Market (EEM), Łódź, Poland, 27-29 June 2018.

23. Hauduc, H.; Rieger, L.; Oehmen, A.; Van Loosdrecht, M.C.; Comeau, Y.; Héduit, A.; Vanrolleghem, P.A.; Gillot, S. Critical review of activated sludge modeling: State of process knowledge, modeling concepts and limitations. Biotechnol. Bioeng. 2013, 110, 24-46. [CrossRef] [PubMed]

24. Ruano, M.V.; Serralta, J.; Ribes, J.; Garcia-Usach, F.; Bouzas, A.; Barat, R.; Seco, A.; Ferrer, J. Application of the general model 'biological nutrient removal model no. 1' to upgrade two full-scale WWTPs. Environ. Technol. 2012, 33, 1005-1012. [CrossRef] [PubMed] 
25. Drewnowski, J.; Remiszewska-Skwarek, A.; Fernandez-Morales, F.J. Model based evaluation of plant improvement at a large wastewater treatment plant (WWTP). J. Environ. Sci. Health. Part A 2018, 53, 669-675. [CrossRef]

26. Van Hulle, S.W.; Ciocci, M.C. Scenario analysis and statistical analysis of simulation results of operation of activated sludge waste water treatment plants. Desalin. Water Treat. 2014, 52, 4154-4164. [CrossRef]

27. Jeppsson, U.; Alex, J.; Batstone, D.J.; Benedetti, L.; Comas, J.; Copp, J.; Corominas, L.; Flores-Alsina, X.; Gernaey, K.V.; Nopens, I. Benchmark simulation models, quo vadis? Water Sci. Technol. 2013, 68, 1-15. [CrossRef] [PubMed]

28. Gujer, W.; Henze, M.; Mino, T.; Matsuo, T.; Wentzel, M.C.; Marais, G.V.R. The activated sludge model no. 2: Biological phosphorus removal. Water Sci. Technol. 1995, 31, 13-23. [CrossRef]

29. Gujer, W.; Henze, M.; Mino, T.; Van Loosdrecht, M. Activated sludge model no. 3. Water Sci. Technol. 1999, 39, 183-193. [CrossRef]

30. Henze, M.; Gujer, W.; Mino, T.; Loosedrecht, M.V. Activated Sludge Models ASM1, ASM2, ASM2d and ASM3; IWA Publishing: London, UK, 2000.

31. Baek, S.H.; Jeon, S.K.; Pagilla, K. Mathematical modeling of aerobic membrane bioreactor (MBR) using activated sludge model no. 1 (ASM1). J. Ind. Eng. Chem. 2009, 15, 835-840. [CrossRef]

32. Gao, F.; Nan, J.; Li, S.; Wang, Y. Modeling and simulation of a biological process for treating different COD:N ratio wastewater using an extended ASM1 model. Chem. Eng. J. 2018, 332, 671-681. [CrossRef]

33. Gernaey, K.V.; van Loosdrecht, M.C.; Henze, M.; Lind, M.; Jørgensen, S.B. Activated sludge wastewater treatment plant modelling and simulation: State of the art. Environ. Modell. Softw. 2004, 19, 763-783. [CrossRef]

34. Ewa, L.B.; Rafal, B. Identification of the most sensitive parameters in the activated sludge model implemented in BioWin software. Bioresour. Technol. 2010, 101, 7278-7285.

35. Martin, C.; Vanrolleghem, P.A. Analysing, completing, and generating influent data for WWTP modelling: A critical review. Environ. Modell. Softw. 2014, 60, 188-201. [CrossRef]

36. Karahan, O.; Dogruel, S.; Dulekgurgen, E.; Orhon, D. COD fractionation of tannery wastewaters-particle size distribution, biodegradability and modeling. Water Res. 2008, 42, 1083-1092. [CrossRef]

37. Karlikanovaite-Balikci, A.; Yagci, N. Determination and evaluation of kinetic parameters of activated sludge biomass from a sludge reduction system treating real sewage by respirometry testing. J. Environ. Manag. 2019, 240, 303-310. [CrossRef]

38. Mathieu, S.; Etienne, P. Estimation of wastewater biodegradable COD fractions by combining respirometric experiments in various So/Xo ratios. Water Res. 2000, 34, 1233-1246. [CrossRef]

39. Sadecka, Z.; Jęrczak, A.; Pèuciennik-Koropczuk, E.; Myszograj, S.; Suchowska-Kisielewicz, M. COD Fractions in sewage flowing into polish sewage treatment plants. Chem. Biochem. Eng. Q. 2013, 27, 185-195.

40. Galvao, A.; Pisoeiro, J.; Pinheiro, H. Storage mechanisms in constructed wetlands: Should we modify heterotrophic bacteria modelling? Sci. Total Environ. 2019, 658, 830-835. [CrossRef]

41. Man, Y.; Shen, W.; Chen, X.; Long, Z.; Pons, M.N. Modeling and simulation of the industrial sequencing batch reactor wastewater treatment process for cleaner production in pulp and paper mills. J. Clean. Prod. 2017, 167, 643-652. [CrossRef]

42. Reijken, C.; Giorgi, S.; Hurkmans, C.; Perez, J.; van Loosdrecht, M.C. Incorporating the influent cellulose fraction in activated sludge modelling. Water Res. 2018, 144, 104-111. [CrossRef] [PubMed]

43. Shoener, B.D.; Schramm, S.M.; Beline, F.; Bernard, O.; Martinez, C.; Plosz, B.G.; Snowling, S.; Steyer, J.P.; Valverde-Perez, B.; Wagner, D.; et al. Microalgae and cyanobacteria modeling in water resource recovery facilities: A critical review. Water Res. $X$ 2019, 2, 100024. [CrossRef]

44. Behin, J.; Bahrami, S. Modeling an industrial dissolved air flotation tank used for separating oil from wastewater, chemical Engineering and Processing. Process Intensif. 2012, 59, 1-8. [CrossRef]

45. Climent, J.; Martínez-Cuenca, R.; Carratalà, P.; González-Ortega, M.J.; Abellán, M.; Monrós, G.; Chiva, S. A comprehensive hydrodynamic analysis of a full-scale oxidation ditch using population balance modelling in CFD simulation. Chem. Eng. J. 2019, 374, 760-775. [CrossRef]

46. Lesage, N.; Spérandio, M.; Lafforgue, C.; Cockx, A. Calibration and application of a 1-D model for oxidation ditches. Chem. Eng. Res. Des. 2003, 81, 1259-1264. [CrossRef]

47. Fernández, X.R.; Nirschl, H. Simulation of particles and sediment behaviour in centrifugal field by coupling CFD and DEM. Chem. Eng. Sci. 2013, 94, 7-19. [CrossRef]

48. Stamou, A.I. Improving the hydraulic efficiency of water process tanks using CFD models, chemical engineering and processing. Process Intensif. 2008, 47, 1179-1189. [CrossRef]

49. Jin, L.; Zhang, G.; Tian, H. Current state of sewage treatment in China. Water Res. 2014, 66, 85-98. [CrossRef]

50. Demoulin, G.; Goronszy, M.C.; Wutscher, K.; Forsthuber, E. Co-current nitrification/ denitrification and biological p-removal in Cyclic Activated Sludge plants by redox controlled cycle operation. Water Sci. Technol. 1997, 35, 215-224. [CrossRef]

51. Liang, W.; Yu, C.; Ren, H.; Geng, J.; Ding, L.; Xu, K. Minimization of nitrous oxide emission from CASS process treating low carbon source domestic wastewater: Effect of feeding strategy and aeration rate. Bioresour. Technol. 2015, 198, 172-180. [CrossRef]

52. Li, L.; Qian, G.; Ye, L.; Hu, X.; Yu, X.; Lyu, W. Research on the enhancement of biological nitrogen removal at low temperatures from ammonium-rich wastewater by the bio-electrocoagulation technology in lab-scale systems, pilot-scale systems and a full-scale industrial wastewater treatment plant. Water Res. 2018, 140, 77-89. [CrossRef]

53. Liu, M.M.; Chen, M.X.; Qi, R.; Wei, Y.S.; Du, H.Z.; Hu, Y.M.; Zhang, X. ASM simulation optimization and practical application on upgrading of urban sewage treatment plant in cold region. Chin. J. Environ. Eng. 2019, 14, 1-19. 
54. Cruz, J.A.S.; Mussati, S.F.; Scenna, N.J.; Gernaey, K.V.; Mussati, M.C. Reaction invariant-based reduction of the activated sludge model ASM1 for batch applications. J. Environ. Chem. Eng. 2016, 4, 3654-3664. [CrossRef]

55. Girou, É.Y.; Spanjers, H.; Patry, G.G.; Takács, I. Dynamic modelling for operational design of a respirometer. Water Sci. Technol. 1996, 33, 297-309. [CrossRef]

56. Lagarde, F.; Tusseau-Vuillemin, M.H.; Lessard, P.; Héduit, A.; Dutrop, F.; Mouchel, J.M. Variability estimation of urban wastewater biodegradable fractions by respirometry. Water Res. 2005, 39, 4768-4778. [CrossRef]

57. Martín, M.; Montes, F.J.; Galán, M.A. Bubbling process in stirred tank reactors I: Agitator effect on bubble size, formation and rising. Chem. Eng. Sci. 2008, 63, 3212-3222. [CrossRef]

58. Brands, E.; Liebeskind, M.; Dohmann, M. Parameters for dynamic simulation of wastewater treatment plants with high-rate and low-rate activated sludge tanks. Water Sci. Technol. 1994, 30, 211-214. [CrossRef]

59. Dosta, J.; Gali, A.; Benabdallah El-Hadj, T.; Mace, S.; Mata-Alvarez, J. Operation and model description of a sequencing batch reactor treating reject water for biological nitrogen removal via nitrite. Bioresour. Technol. 2007, 98, 2065-2075. [CrossRef] [PubMed]

60. Dircks, K.; Pind, P.F.; Mosbæk, H.; Henze, M. Yield determination by respirometry-The possible influence of storage under aerobic conditions in activated sludge. WATER SA 1999, 25, 69-74.

61. Hu, Z.; Chandran, K.; Smets, B.F.; Grasso, D. Evaluation of a rapid physical-chemical method for the determination of extant soluble COD. Water Res. 2002, 36, 617-624. [CrossRef]

62. Zhou, M.; Gong, J.; Yang, C.; Pu, W. Simulation of the performance of aerobic granular sludge SBR using modified ASM3 model. Bioresour. Technol. 2013, 127, 473-481. [CrossRef] [PubMed]

63. Abasaeed, A.E. Sensitivity analysis on a sequencing batch reactor model I. Effect of kinetic parameters. J. Chem. Technol. Biotechnol. 2010, 70, 379-383. [CrossRef]

64. Barnwell, T.; Brown, L.; Marek, W. Development of a Prototype Expert Advisor for the Enhanced Stream Water Quality Model QUAL2E; Environmental Research Laboratory Office of Research and Development: Triangle Park, NC, USA, 1986.

65. Petersen, B.G.K.; Henze, M.; Vanrolleghem, P.A. Calibration of activated sludge models: A critical review of experimental designs. In Biotechnology for the Environment: Wastewater Treatment and Modeling, Waste Gas Handling. Focus on Biotechnology; Agathos, S.N., Reineke, W., Eds.; Springer: Dordrecht, The Netherlands, 2003; Volume 3C.

66. Brannock, M.W.D. Computational Fluid Dynamics Tools for the Design of Mixed Anoxic Wastewater Treatment Vessels. Bachelor's Thesis, The University of Queensland, Brisbane, Australia, 2003.

67. Climent, J.; Basiero, L.; Martínez-Cuenca, R.; Berlanga, J.G.; Julián-López, B.; Chiva, S. Biological reactor retrofitting using CFD-ASM modelling. Chem. Eng. J. 2018, 348, 1-14. [CrossRef]

68. Marais, G.; Ekama, G. The activated sludge process part I-steady state behaviour. Water SA 1976, 2, 163-200.

69. Qiu, F.G.; Zhang, X.; Gao, H.W. Discussion of ICEAS process simulation and upgrade based on biowin software. Water Wastewater Eng. 2015, 51, 100-105. (In Chinese)

70. Wu, Z.C.; Wang, Z.W.; Tang, S.J.; Gu, G.W. Activated sludge model based COD fractionation in wastewater characterization. Environ. Sci. 2010, 31, 1478-1482. (In Chinese)

71. Lu, P.; Zhang, X.; Zhang, D. An integrated system for wastewater COD characterization and a case study. Water Sci. Technol. 2010, 62, 866-874. [CrossRef]

72. Henze, M. Characterization of wastewater for modelling of activated sludge processes. Water Sci. Technol. 1992, 25, 1-15. [CrossRef]

73. Kappeler, J.; Gujer, W. Estimation of kinetic parameters of heterotrophic biomass under aerobic conditions and characterization of wastewater for activated sludge modelling. Water Sci. Technol. 1992, 25, 125-139. [CrossRef]

74. Okutman, D.; Övez, S.; Orhon, D. Hydrolysis of settleable substrate in domestic sewage. Biotechnol. Lett. 2001, 23, 1907-1914. [CrossRef]

75. Zhang, T.; Shao, M.F.; Ye, L. 454 Pyrosequencing reveals bacterial diversity of activated sludge from 14 sewage treatment plants. ISME J. 2012, 6, 1137-1147. [CrossRef] 